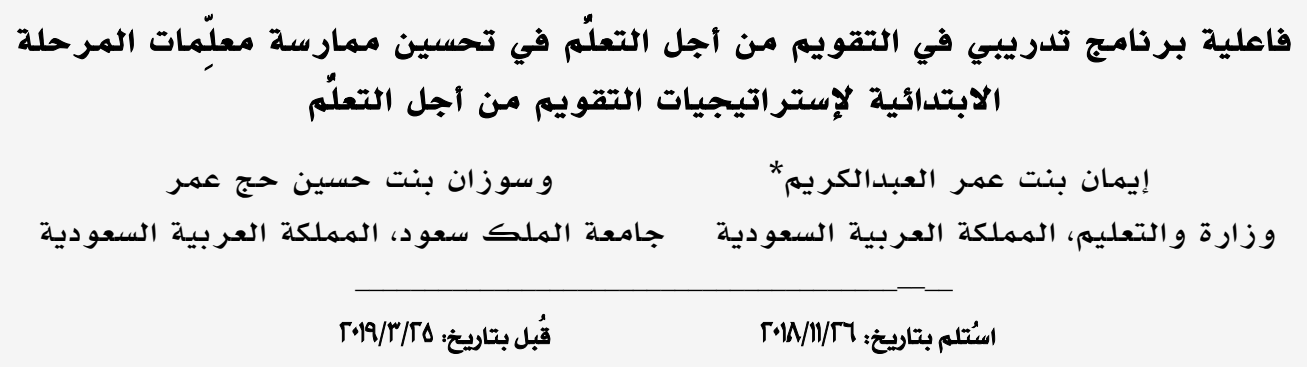

The Effectiveness of an Assessment for Learning Training Program in Improving the Practice of Primary School Teachers of Assessment for Learning Strategies

Eman O. Abdulkareem*

\& Sozan H. Haj Omar

Ministry of Education, Kingdom of Saudi Arabia King Saud University, Kingdom of Saudi Arabia

\begin{abstract}
The purpose of this research was to investigate the effectiveness of a training program on "Assessment for Learning" on enhancing elementary teachers assessment for learning practices in their classrooms. One hundred and seventy one teachers attended the training program that was held eight times throughout the semester. A pretest and posttest were implemented on all trainees, mean differences were calculated using the paired-samples $t$ test. Fifty-six of the teachers answered an open-ended survey to collect qualitative data to support quantitative results. Significant differences between pre and post-test means in favour of the latter were found, which illustrates that the program had helped the teachers to develop knowledge of assessment for learning concepts and strategies. Seven assertions emerged from qualitative analysis: Safe Learning Environment, Turning Competition into Collaboration, Developing Thinking Skills, SelfRegulated Learning, Developing Life Skills, Enhancing Motivation, and Learning is for All.
\end{abstract}

Keywords: Continuous assessment, professional development, elementary grade teaching. $\star$ omarso@ksu.edu.sa 


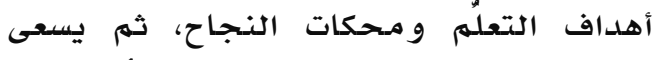

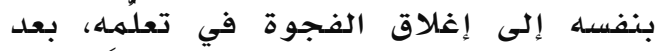

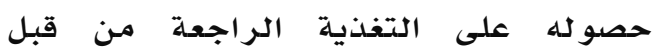

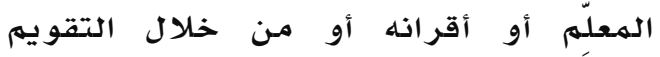
الذاتي؛ التي توجهه نحو كيفية تحسين

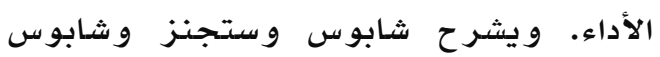

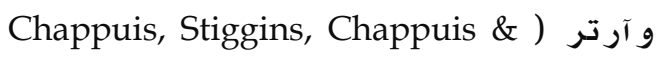
(Arter, 2012 كيف تتم الهر اقبة الذاتية للمتعلّم، وتحديل خطو اتها له: (1) معر فة المتعلّم للأهداف التي يسعى إلى

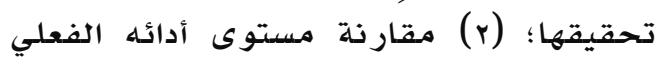

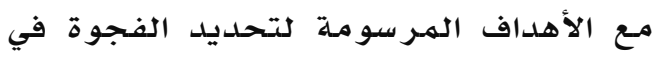

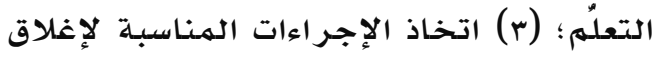

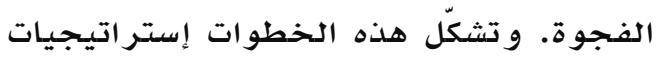

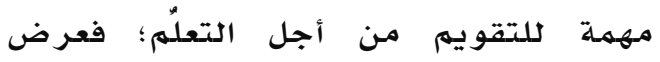

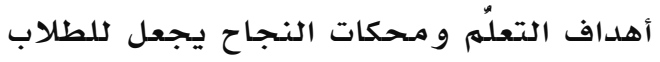

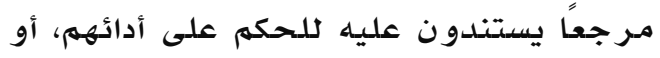

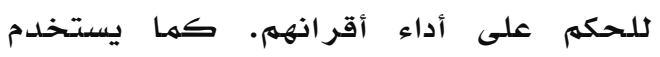

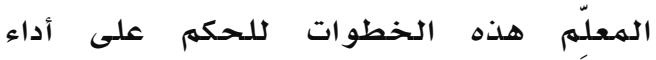

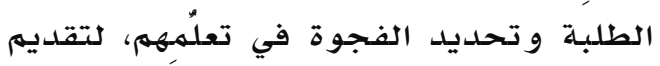
التغذية الر اجعة المناسبـة التي ترشدهم إلى تحسين الأداء. كما يرتكز التقويم من أجل التعلِم على معلى معات

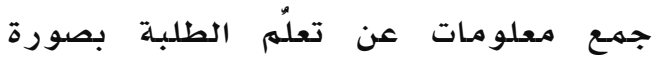
متززامنـة مـع التدريس، لاتخاذ قرارات توجّه

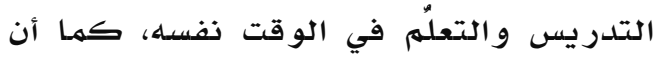
الرقي بالأسئلة إلى مستويات التفكير العُليا

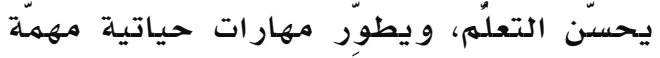

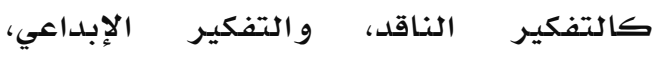

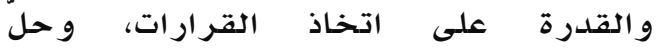

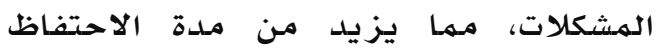
بالمعارف والمهارات، و يجعلها أكثر فائدة لحياة الطلبة، كما تتطور لديهم اتجاهات

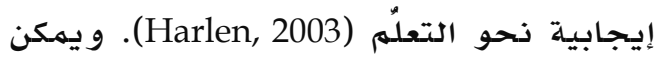

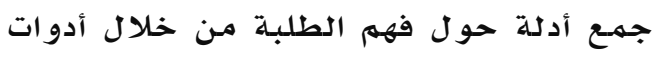

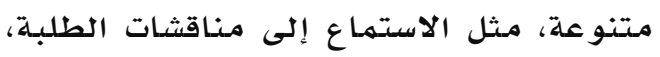

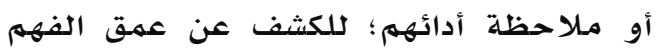

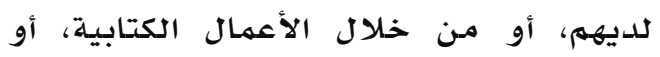

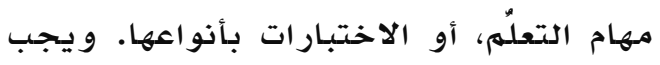

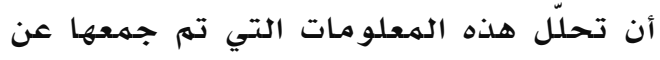

يُعد التقويهم أحد أركان المنهج الذي يهدف

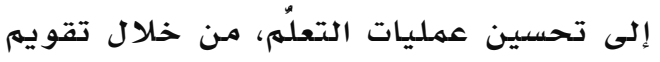

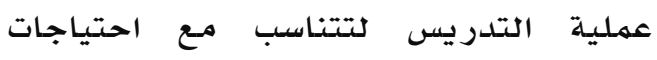

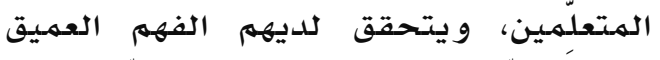

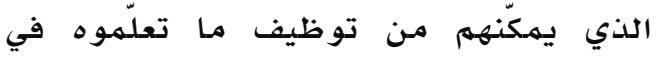

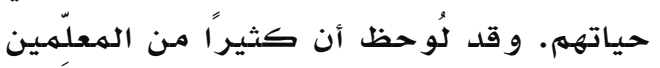
يفضلون تأجيل عملية التقويم إلى نهاية

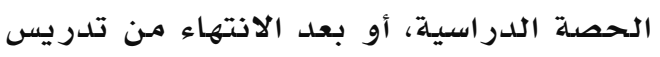

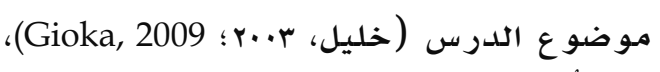
فيصعب بذلك إجر اء عمليات تحسين الأداء.

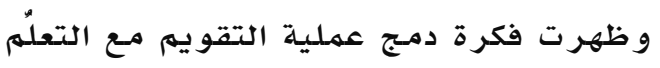

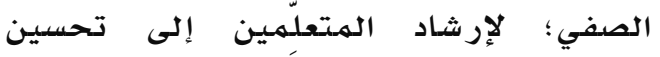

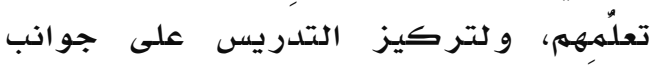

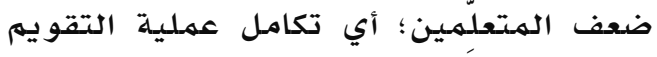

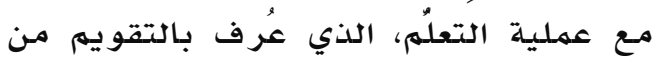

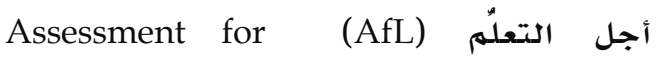

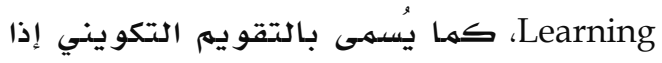
تبعته عمليات تحسين الأداء. ير تكز التقويهم من أجل التعلّم على المـراقبة

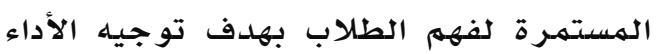

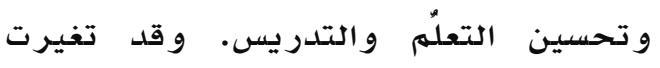

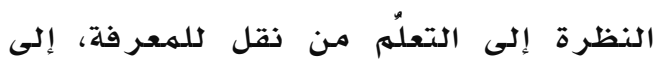

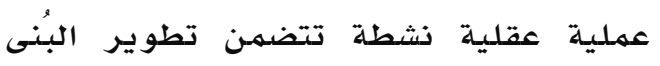
المعرفية من خلابه استيعاب المفاهيه

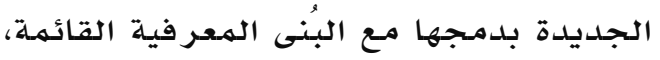

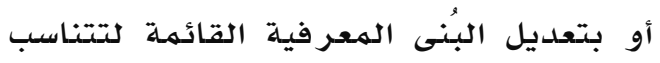
مـع المعر فة الجديدة وفق النظرية المعر فية (Piaget \& Inhelder, 1969) النظرة البنائية للتعلّمَ أن يكون المتعلّمَ

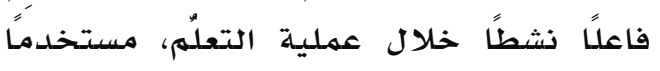
هذه الخبرات والههارات في تعلّم مفاهيم جديدة، كما تتطلب منه في الوقت نفسه أن

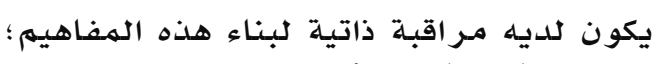
أي تقو يمها ذاتيًا للتعلْم (Shepard, 2000). وقد تعمقت هذه الفكرة بعد مراجعة بلاكك

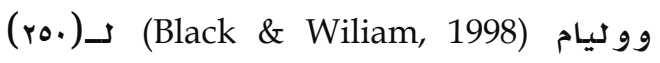

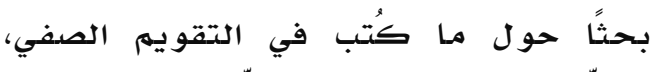

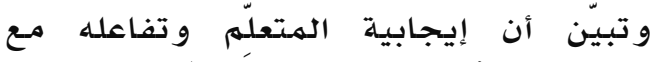

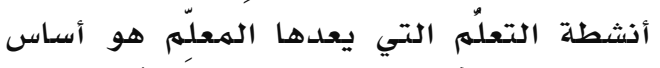

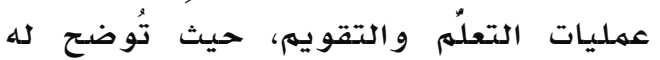




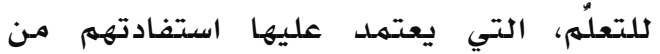

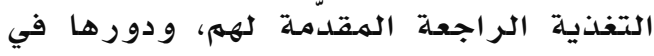

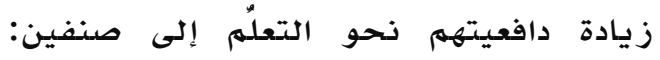

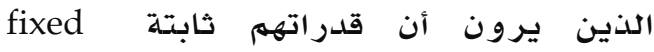
mindset

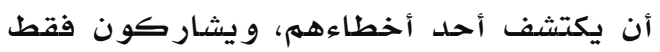
في الأنشطة ذات الطابع السهل التي يهكنهم آنها إتقانها دون مواجهة أي صعوبات أو إخفاق، و الذين يرون أن قدراتهم نامية إنهات

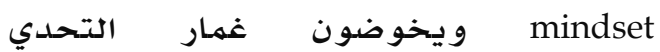
ويبادرون بالهشاركة في جميع الأنشطة دون تردد، حتى لو اتسمت هذه الأنشطة

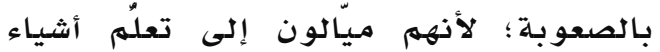
جديدة، ويسارعون في تعديل الأخطاء بعد إند

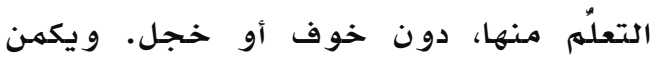

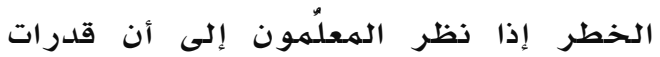
بعض الطلبـة ثابتة، و أنه لا يهكنهم تحسينها،

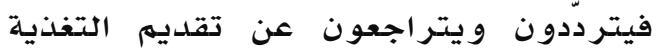
الر اجعة التي تدفع تعلُمهمهم إلى الأمام. تتحدث هير اتج (Heritage, 2010) عن أهمية البيئة الصفية التي يشعر فيها الطالب بالأمان والحرئهة التامـة في طرح الأسئلة

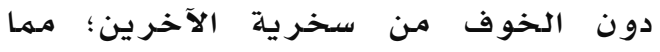
يساعده على الاستفسار عن ما صأ صعب فهمهـ

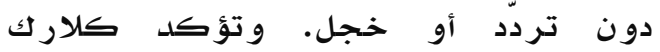
أهمية توفر الحوار والتأمل ولون (Clarke, 2008)

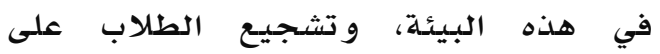

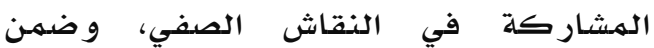

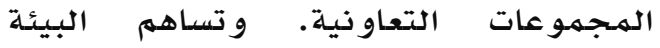
الصفية الآمنـة في توليد أفكار الطلبـة و تعزيزها، وتساعد في تعديل المفاهيم

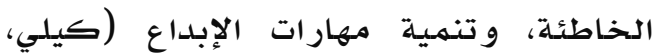
. (r.)

و يسعى أنموذج العبدالكريم و الشايع (17) للتقويهم من أجل تعلّم العلوم إلى إيجاد إدهاد بيئة

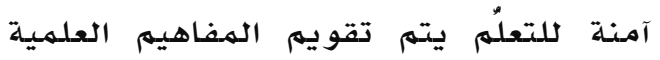

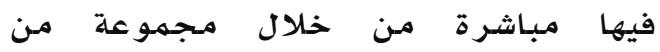

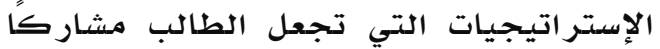

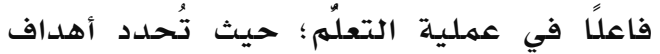

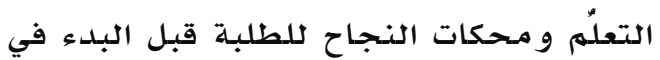

تعلّم الطلبة مـن قبل المعلّم أو الطالب

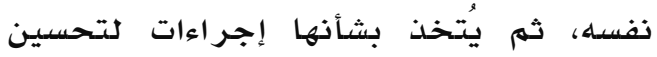

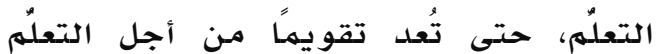
.(Shepard, 2000)

كما أن من إستراتيجيات التقويهم من أجل

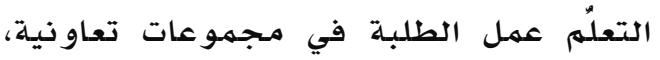
حيث يقوم الأقران بتقويم بعضهم البعض مض البه

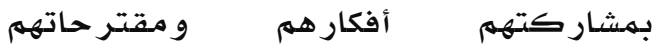
وقراراتهم واتحكم مليها بعد مقارنتها

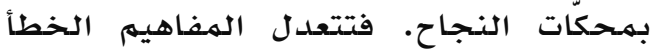
مباشرة بين أعضاء المجموعة نتيجة تبـادل

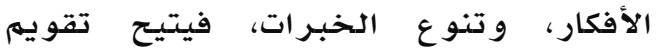
الأقران الفرصة لكل طالب لتعديل الأداء

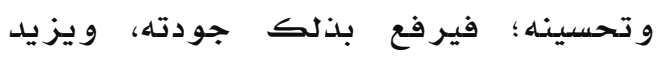

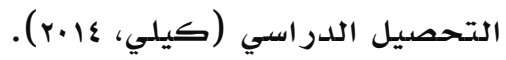

ينتقد بلاك وو ليام (Black \& Wiliam, 1998)

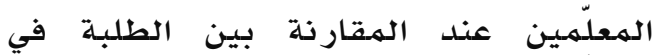
أدائهم أو سرعة إنجازهم للهمام، حيث إن إن تلك المقارنات تعيق عمليات التحسين التهارين

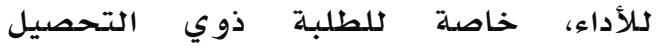
المنـخفض، حيث توحي لهم تلك الإجراءات

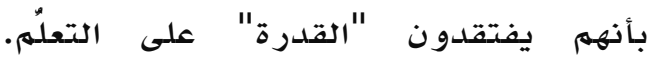

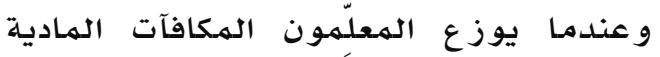

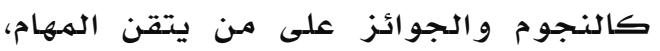
فسيدفع ذلك الطلبة إلى البحث عن مهام

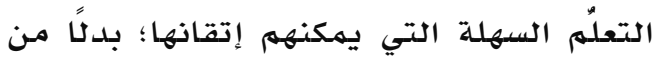

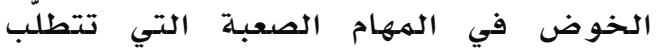

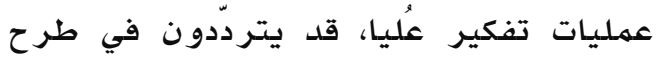

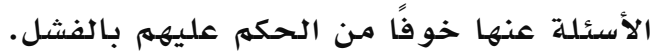
و تؤكد دراسـة دويك (Dweck, 2006) ما ذكره بـلاك ووليام حول الهقارنة بين

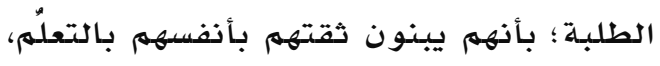

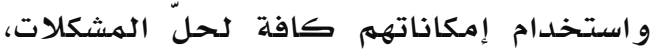
وليس بإثبات أنهم أفضل مـن أقرانهم.

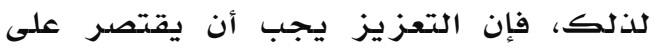
دعم الجهود المبذولة في تحسين الأداء، دون

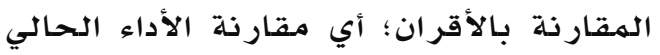

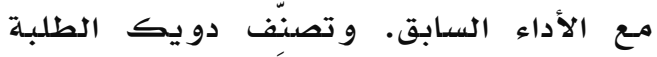

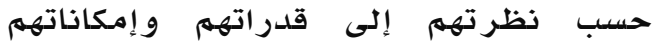




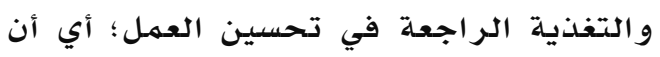

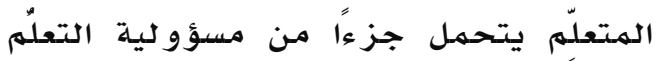
في التقويم الذاتي.

و أكَّ كوه و لين وتان وحبيب ( Koh, Lim, مفوم (Tan \& Habib, 2015

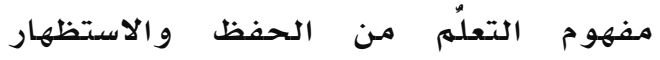
للمعارف، إلى تنمية مهارات التفكير العُليا،

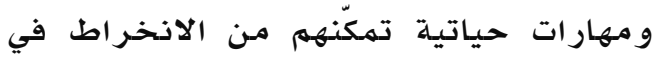
سوق العمل، وأن تسعى المؤسسات التعليمية

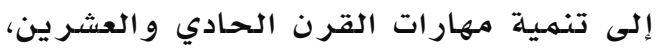

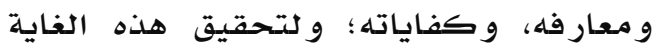

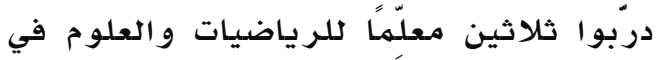

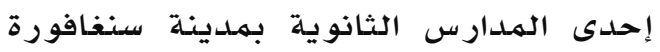

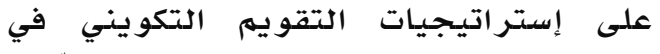

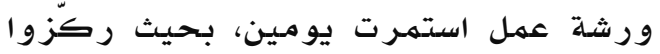

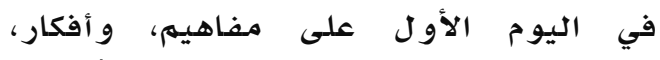

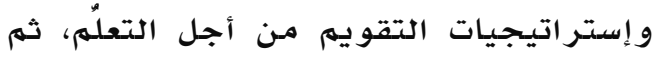

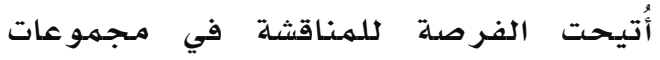

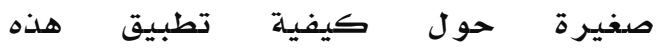

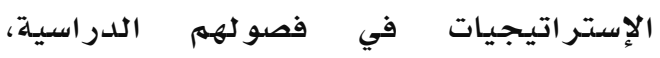

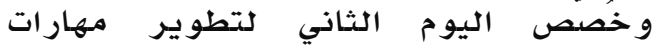

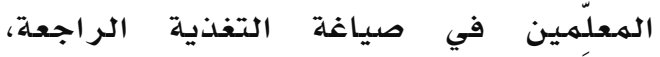

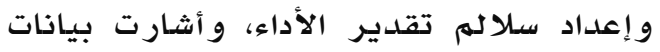

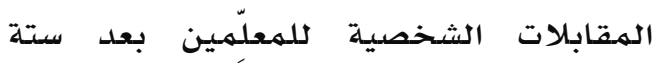
أشهر من ورشة العمل إلى وجود معيقات الهات الهات حالت دون تطبيقهم لإستراتيجيات التقويه

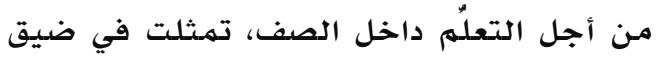
الوقت المخصص للتدريس، وكثرة أعباء المعلّمين وتشعبها، وضعف المعرفة والثة والثقة في إستراتيجيات التقويم من وأجله وضعف التعلُهم، مما أثار الحاجة لتوفير تطوير مهني فعال

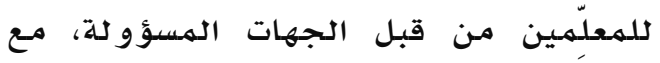

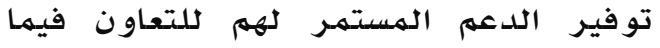

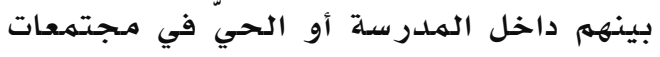

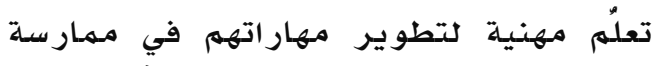
إستر اتيجيات التقويم من أجل التعلُّم.

و أكّد كارك (Clark, 2012) بعد تحليل

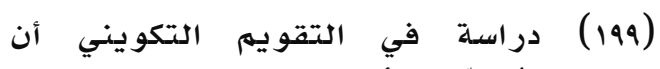

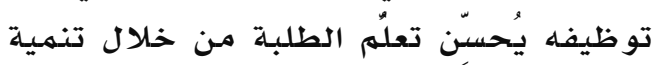

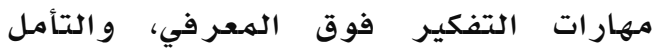

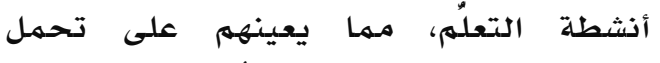

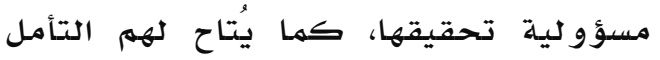

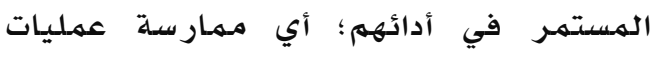

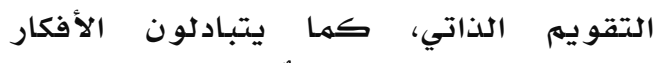

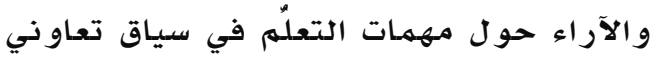

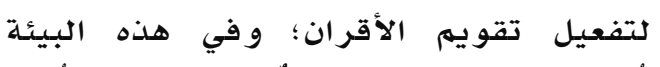

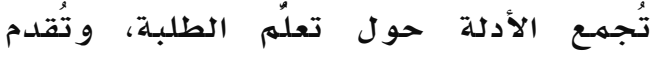
التغذية الراجعة بصورة مستمرة من الأدل الجل

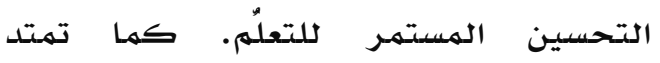

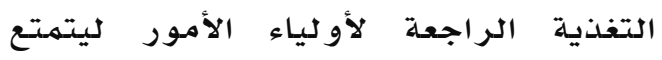

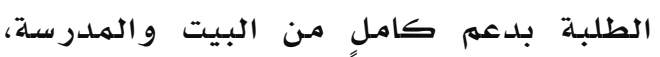
كذلك يدعم الأنموذج المهار ات الاجتماعية ولهية

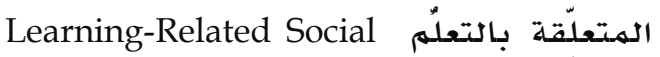

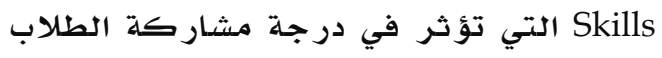

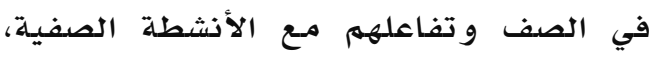

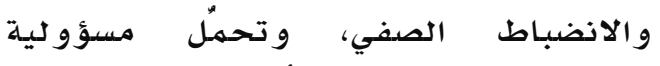

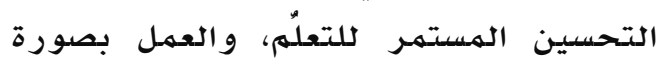

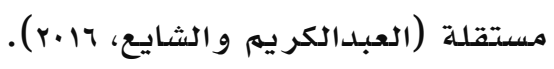

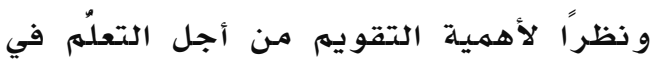

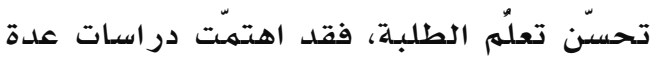

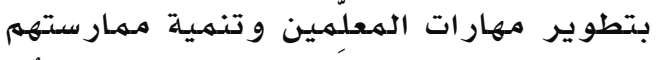

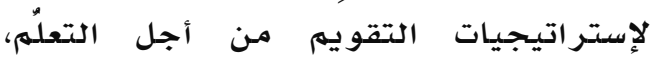

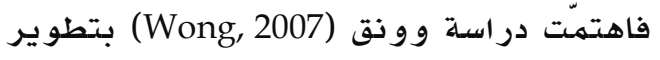

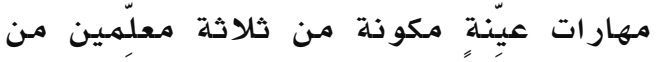

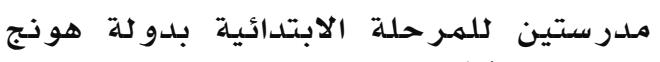

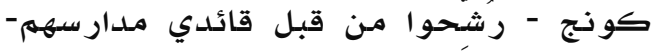

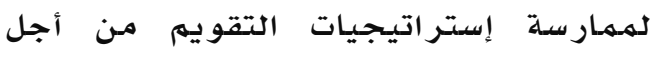

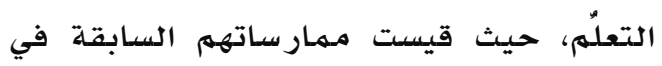

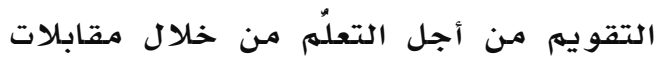

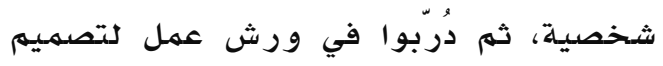

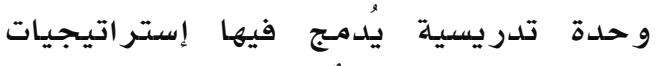

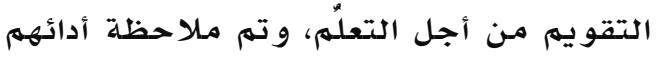

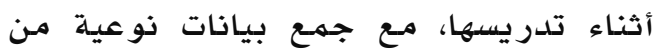

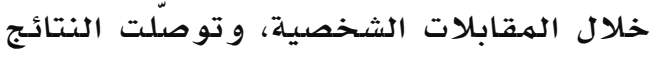

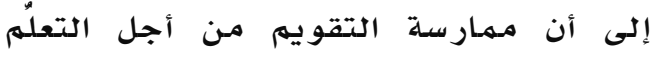

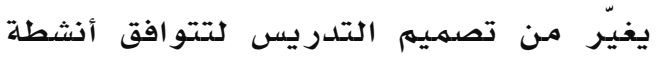

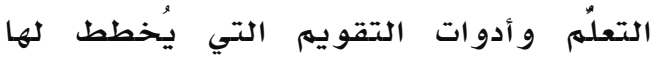

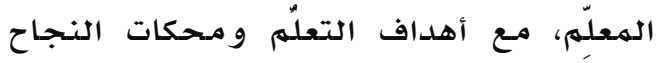

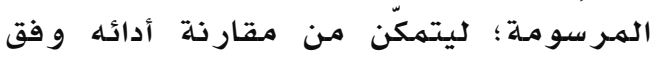

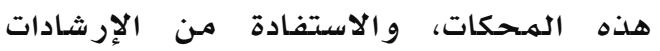


برامج التطوير الهمني مـع الهمارسات اليومية للمعلِمين، على ألا تكون أعباء

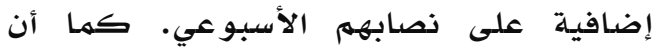

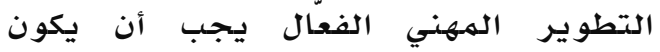

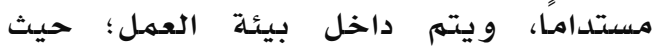
يتعاون المعلّمون في مجتمعات تعلّمَ مهنية تركّز على تطوير المهمارسات التدرويسية، و نتائج الطلبة التحصيلية. جُمعتُ البيانات

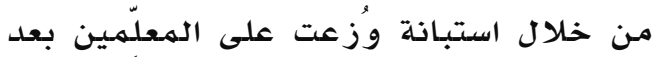

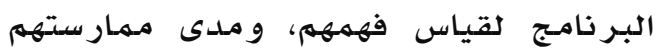
في السابق، ورغبتهم الهستقبلية في مـمارسة

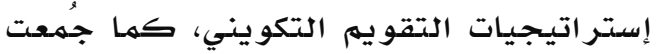

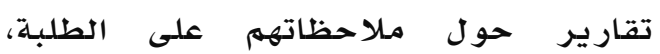

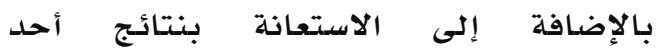

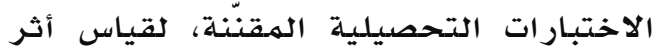

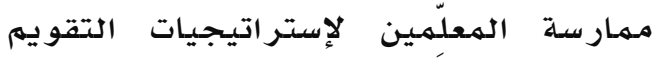
التكويني على تحصيلهم الدراسي. وقدد تبين

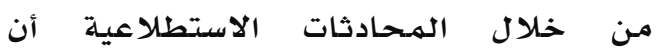

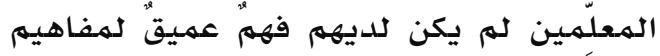

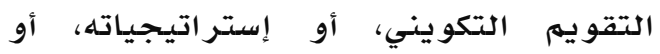

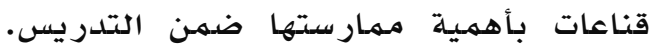

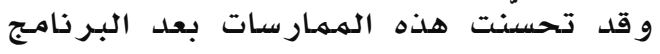

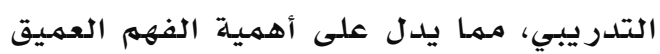

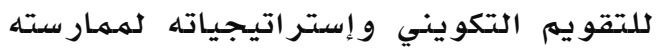

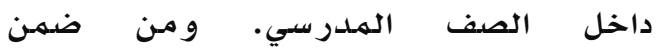

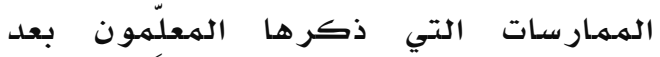

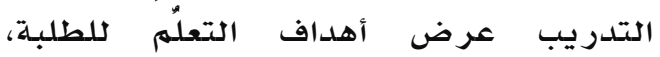

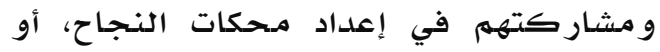
سلالهم تقدير الأداء، التي كان فهان لها الأثر

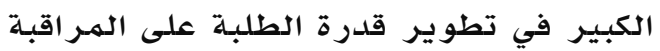

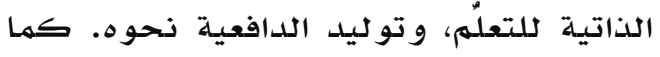
تطورّت مهارات المعلّمسين في تقديهم التغذية

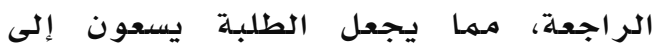

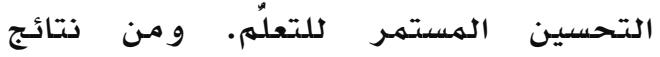
الدراسـة أيضًا تغير دور الطالب والهعلّم،

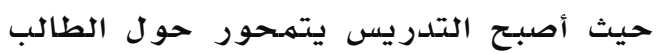

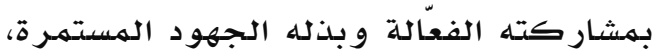

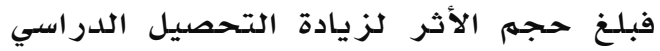
. $(\cdot, \varepsilon 1)$
الهستهـر في الأداء، وومراقبـة تقدمهم نحو

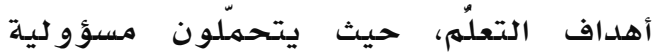

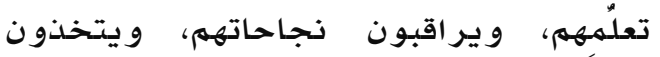
القرارات المؤدية إلى مـزيلد مـن النجاحات،

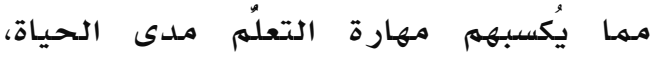
بالإضافة لازدياد دافعيتهم رغهم رغهم الصعوبات

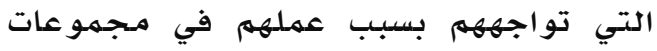

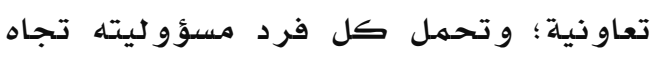

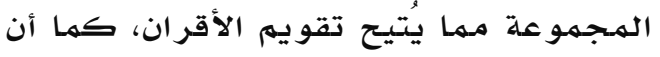

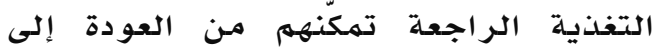

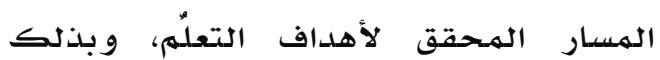

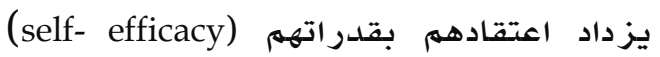
على إنجاز مهام التعلّمَ بإتقان. ولأن" أفضل أنواع التطوير الههني هو

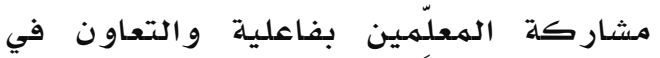
الاستقصداء العلهمي عن جانب التطوير المهني

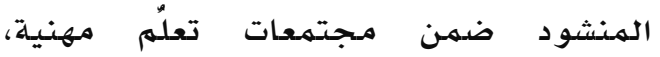
و لتحقيق الشراكة الهمتهعية وتفعيل دور الجامعات في الرقي بمستوى أداء المدارس؛ سعى روبنسون و ومايرن وستروس ورئ وريد (Robinson, Myran, Struass \& Reed, 2014) إلى إعداد برنامهج تطوير مهني تعاوني بين الجامعة و مدارس إحدى المدئ المناطق الأمـريكية،

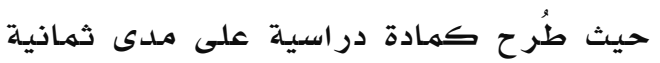

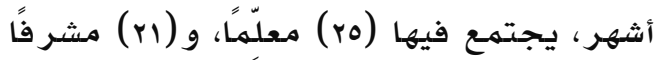
وقائد مدرسة لمدة ثلاث ساعات؛ لتطوير

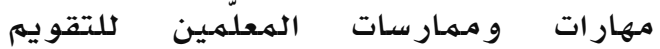
التكويني وشرح مفاهيمـه و إستر اتيجياته، وتنفيذ أنشطة تعاونية لدمـج إستراتيجيات

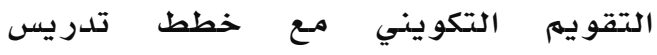

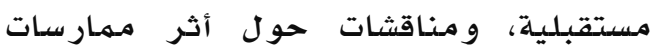

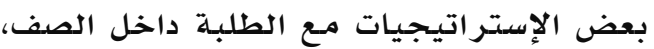

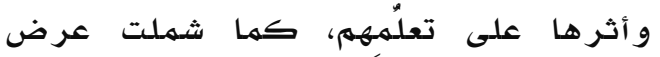

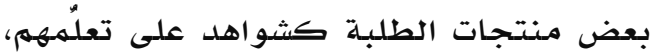
و مناقشات حول سبّل تحسين مهارسات

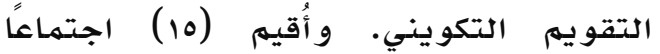
يفصل بينها مدة زمنيـة ما بين أسببوع إلى ألى

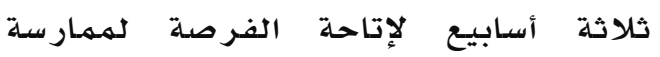
التقويم التكوينـي ودمجـه مـع التدريس. وقد التد

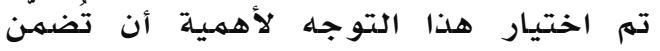


الأدلة التي يجمعها المعلّم حول فهم الطلبة،

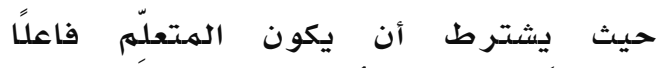

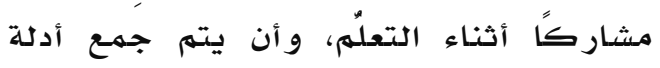

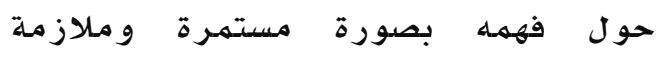
للتدريس، مـع تقديم التغذية الراجعة التهدي

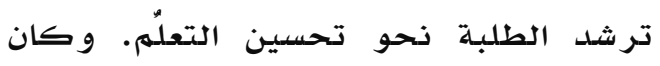

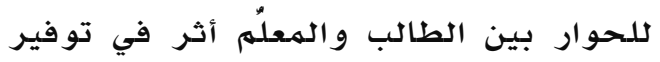

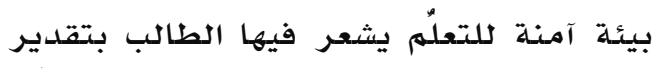

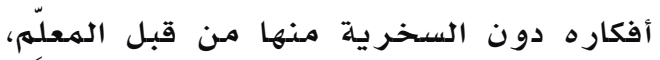

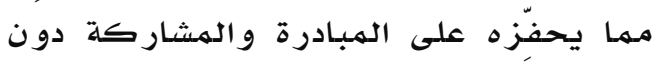

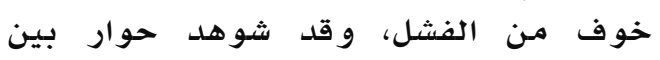

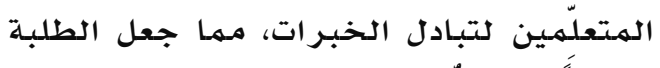

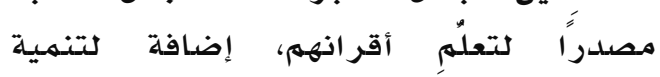

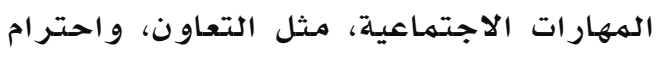

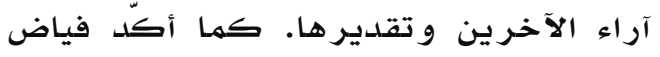
(Fayadh, 2017)

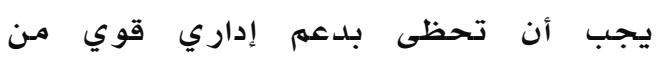

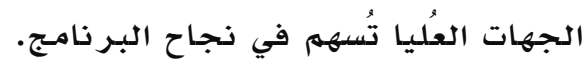

و على غرار هذه الدراسات سعت الباحثتان

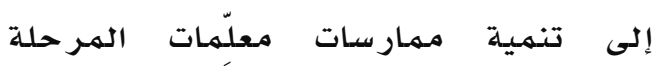

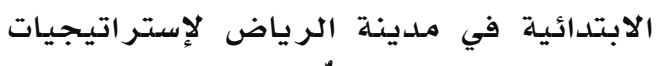

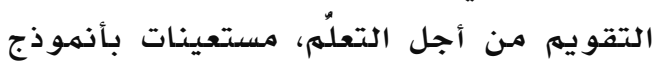

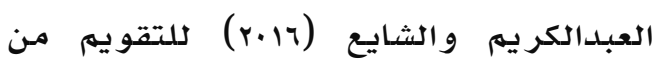
أجل التعلِم الذي قد طورّ في البيئة ذاتها.

\section{مشكلة اللدراسة}

توجهت وزارة التعليم نحو التقويم من أجل

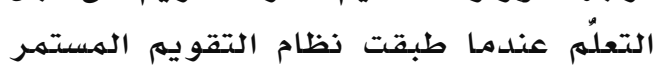

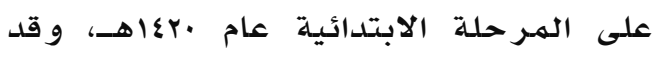

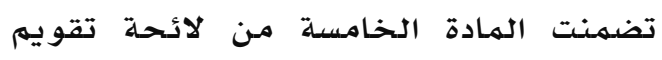

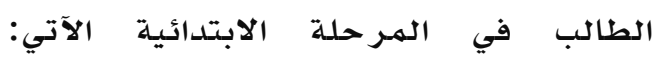

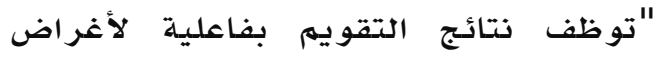

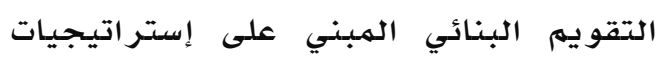

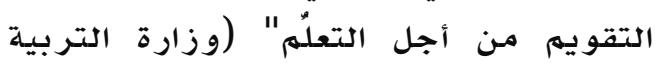

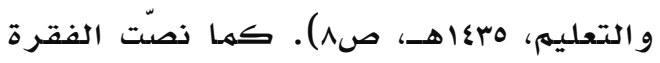

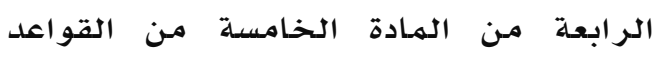
التنفيذية للتقويهم في المر حلدة الابتدائية على "وذلك للدور التقويم البنائي في التئي

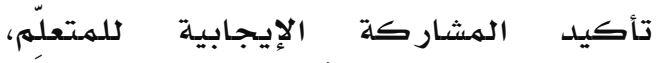

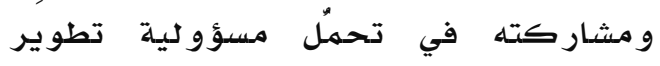

ولهم تجد الباحثتان سدوى دراسة عربية

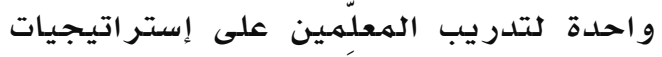

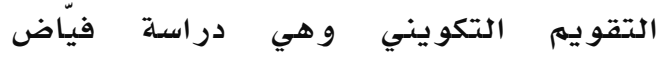
(Fayadh, 2017) فعالية بر نامج تدريبي استمر لهدة (10) جلسـة تدريبية لتطوير مهارات (17) معلِّةًا

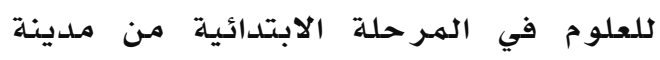
سكاكا في إستراتيجيات التقويم التكويني،

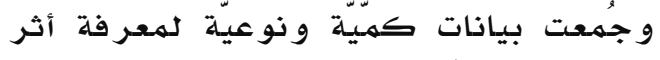

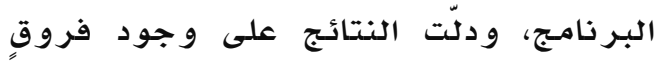

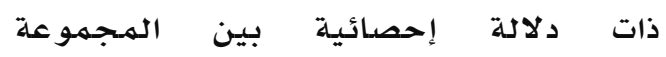

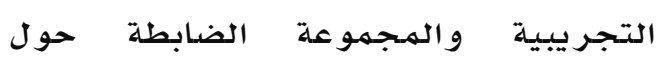

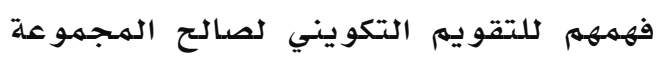

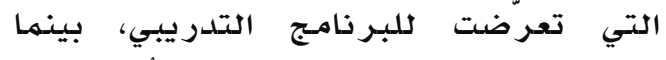

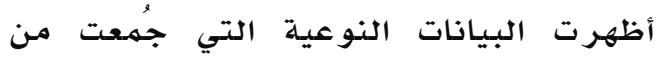

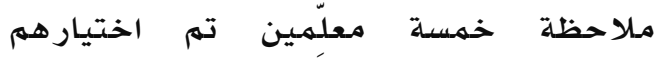

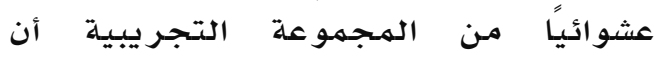

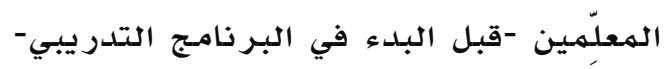

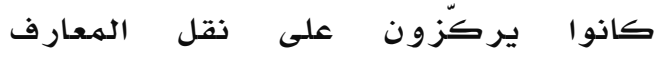

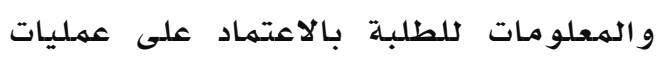

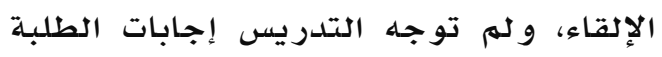

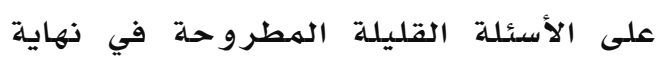

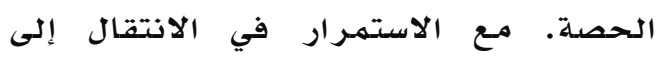

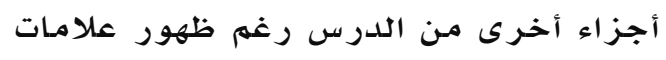

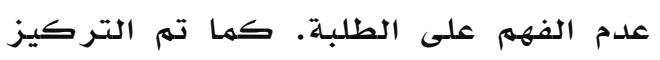
على تحسين أداء الطلبـة ذوي التهيم التحصيل المرتفع أكثر من الاهتمام بالطلبـة ذوي

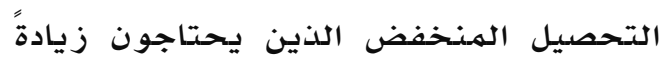

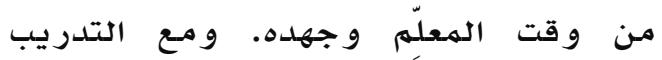
لوحظت سمات أخرى للتدريس سيطرت

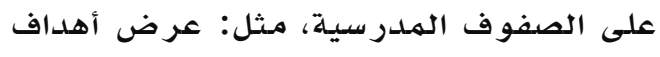

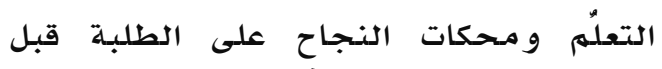

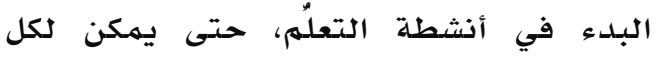

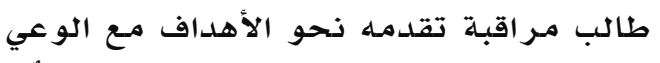

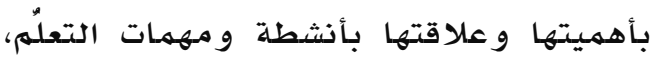

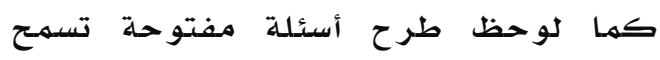

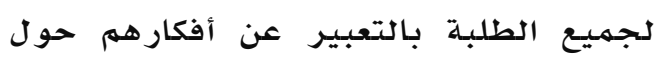

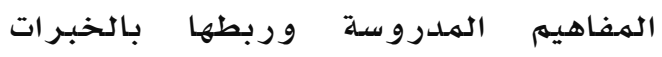
الخاصدة لكل طالب، كما تسهمح بالتعبير عن ونه

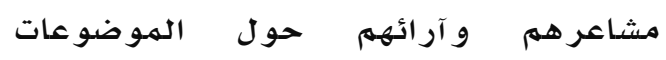

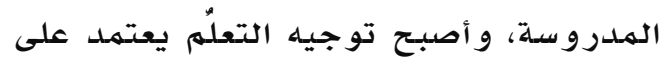


على ممارسات المعلّمات لإستر اتيجيات

التقويم من أجل التعلُم في صفوفهن أهداف الدراسة: هدفت الدراسة إلى التعرف

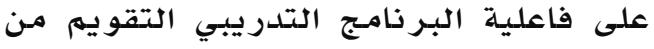

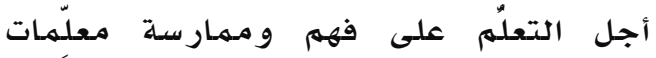

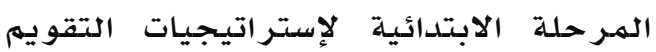

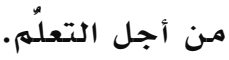

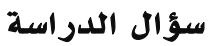

سعت الدراسة للإجابة عن سؤال: ما فاعلية

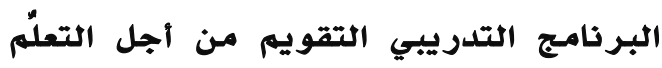

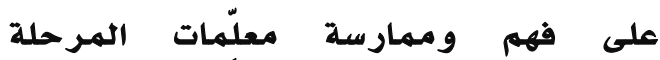

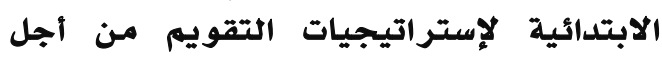
التعلّمى الابتَ

أهمية الدراسة: تتركز أهمية الدراسة في تراسية

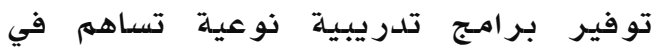

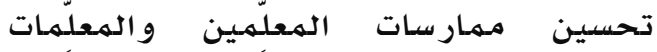

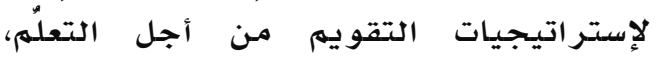

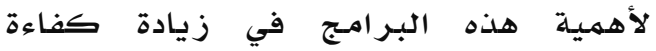

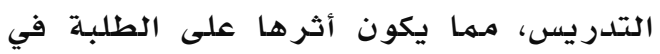

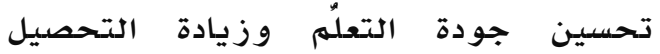

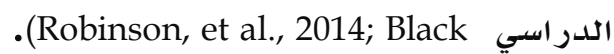
\& Wiliam, 1998; Clark, 2012)

محدّدات الدراسة: تم إجراء الدراسة ضهمن

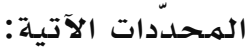

الحدود الزمنية: تم تدريب معلّمات العيّنة

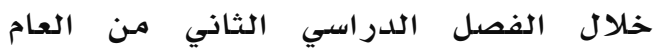

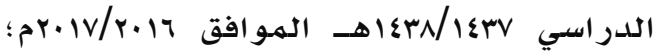
أما المقابلات الشخصية فقد تمتّ خلال الفصل الدراسي الثاني من العام الدراسي الداتي

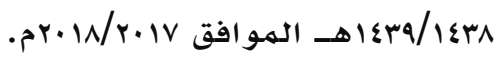
الحدود المكانية: تم تدريب معلّمات العيّنة

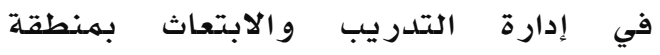
الرياض، وتم إجراء المقابلات الثخصية

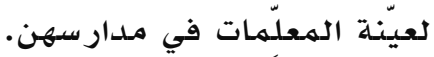

مصطلحات الدراسة: التقويم من أجل

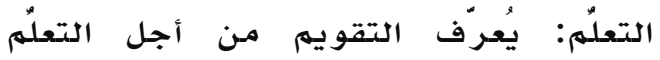

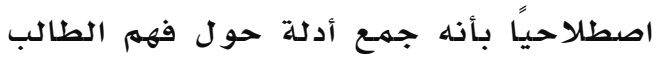

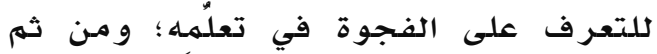

أدائه، وتحقيق المستوى المنشود من

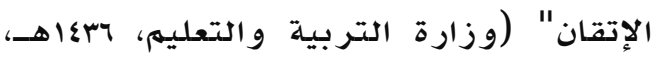

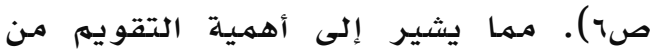

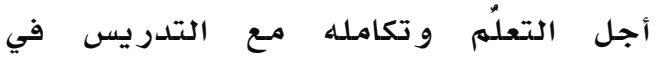

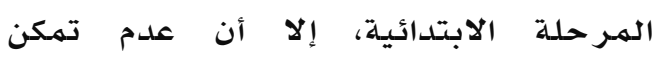

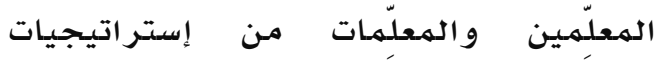

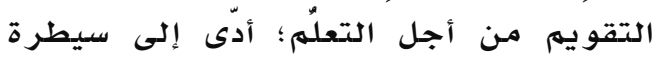

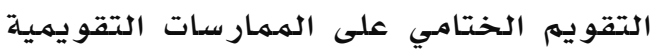
عند كثير منهم.

لذلك، أطلقت إدارة التدريب والابتعاث التباث بمنطقة الرياض مبادرة التقويم من أجل التهاء

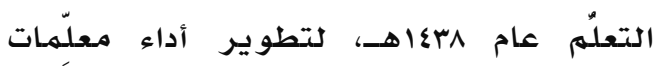

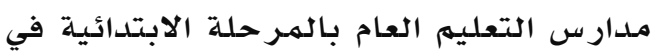

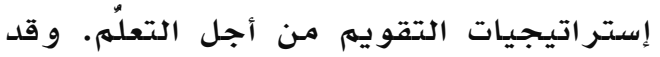

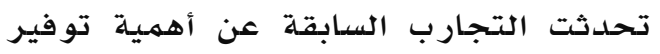

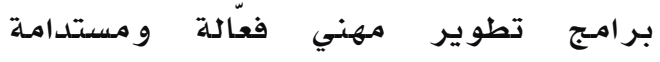

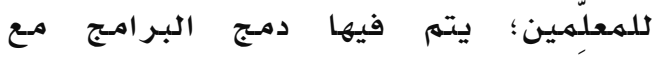

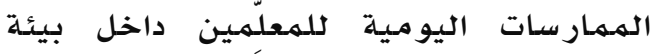

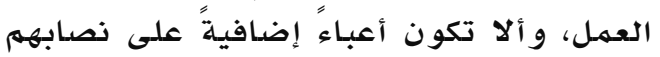
الأسبوعي. إنما يتشاركون ألكون أعباء إضافية فيما بينهم في فياري

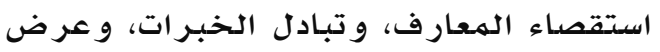

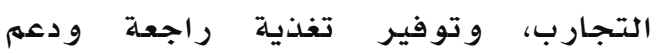

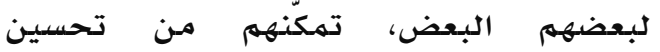

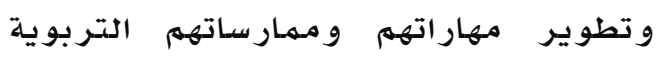
Robinson, et al., 2014; Koh, et al., 2015; ) (Wong, 2007 لإكساب المعلّمات مهارات

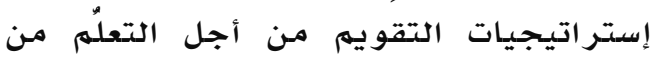

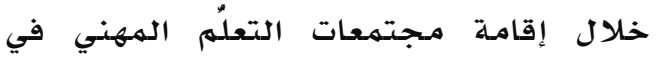

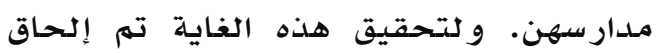

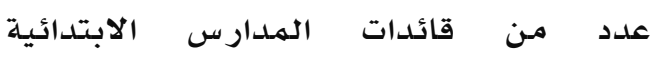

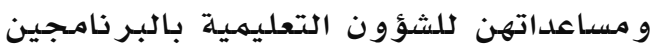

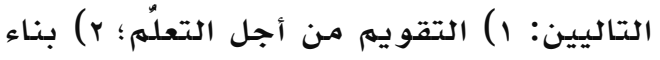

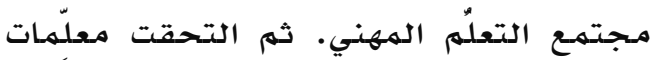

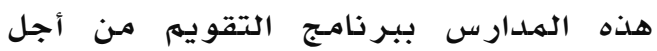

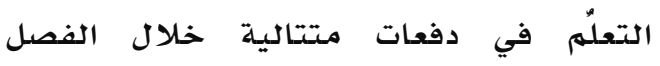

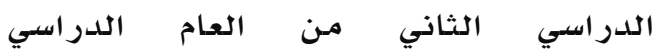

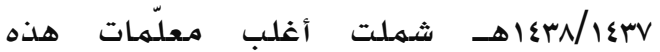
المدارس. فما أثر هذا البرنامج التداريبي 
من أجل التعلُمَ في صفو فهن؛ فقد تمّ اختيار

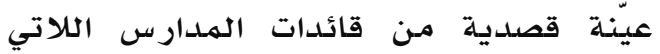
يتوفر فيهن الرغبة والحماس والاستعداد للمشاركة في الدراسة و وتطوير مهارات

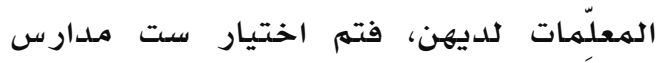

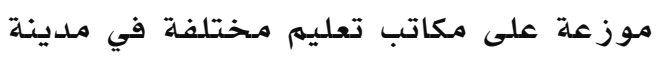

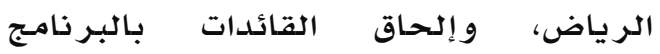

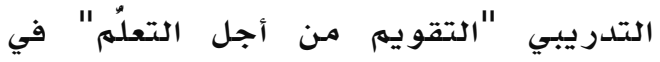

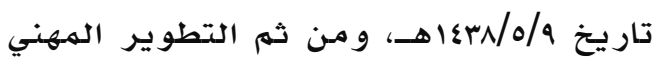

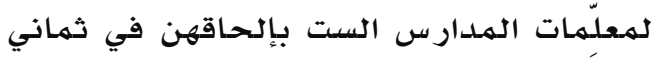
دورات متتالية خلال الفصل الدراسي الثاني

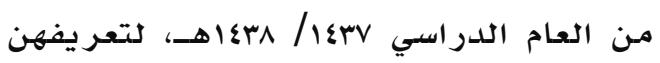

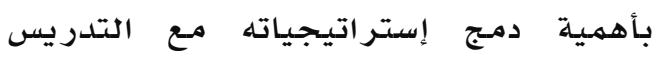

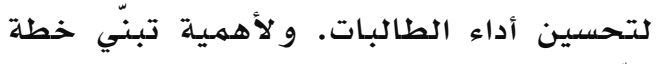

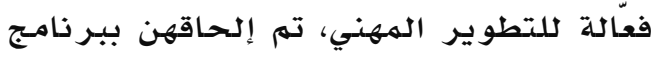

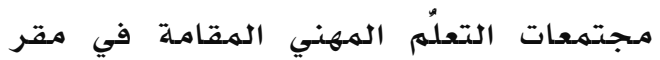

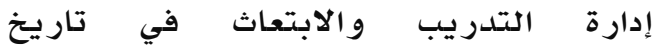

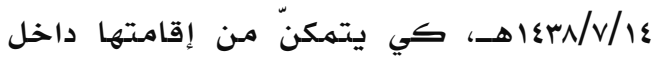
مدارسهن؛ ليتهم التطوير المهني لمعلِّماتهن

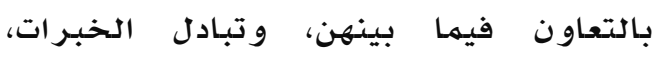

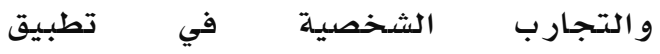
الإستراتيجيات المختلفة للتقويم من أجل النه فئل

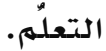

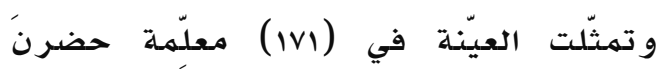

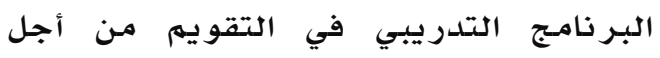

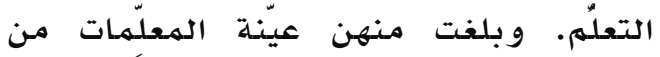

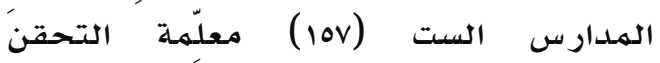

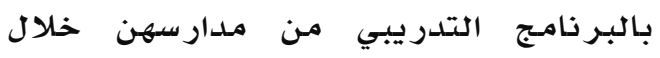

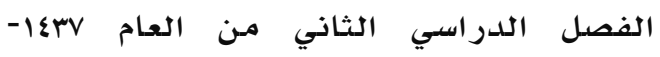

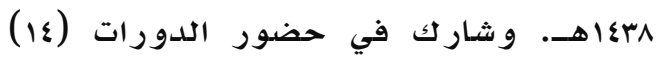

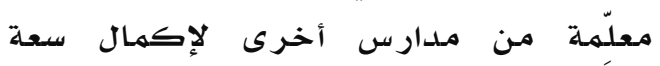

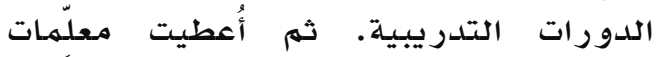

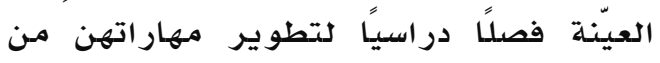
خلال التعاون مـع زميلاتهن في مجتمعات

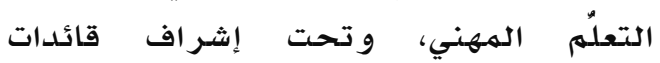

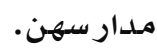
و لرفع الصدق الداخلي للبحث وتخفيف أثر

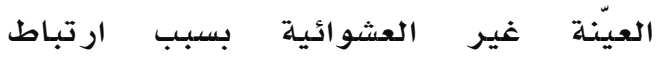

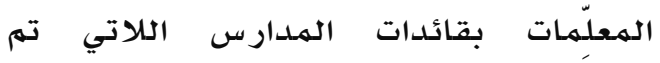
اختيارهن بصورة قصدية؛ تم زيادة حجمها الهماتهات
محاولة تقليص هذه الفجوة بتقديم تغذية راجعة، أو بإحداث تغييرات في إستر اتيجيات

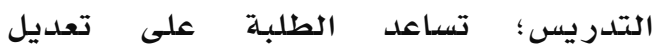

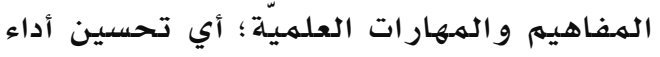

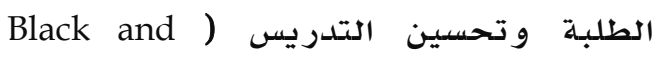
إجرانيًا إجر ائيًا بأنه التقويم الصفي الذي يهدف إلى تحسين التعلُم.

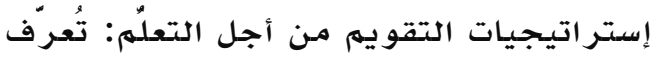

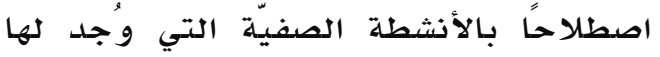

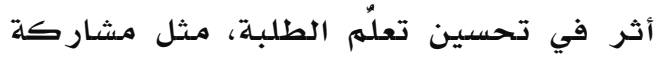

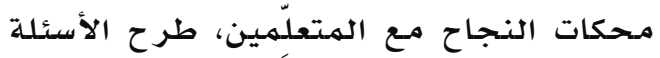

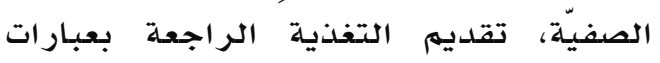

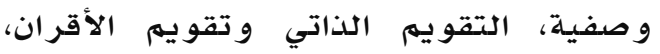

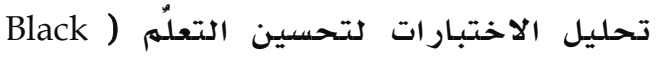

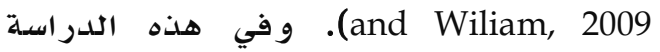

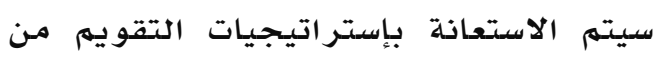

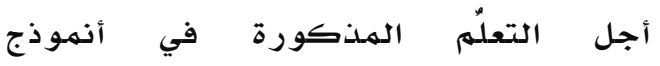

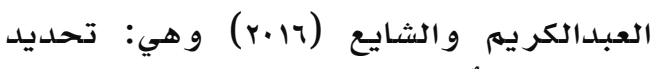

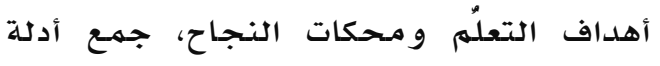

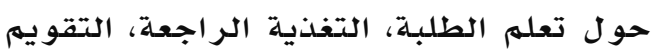
الذاتي، تقويم الأقر ان.

\section{منهجية الدراسة}

تم تطبيق المنهج المُختلط Mixed-method approach

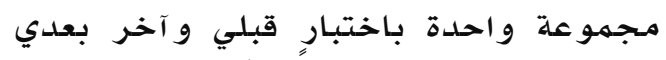

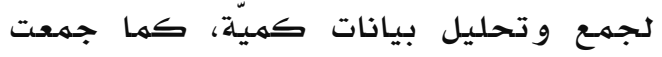

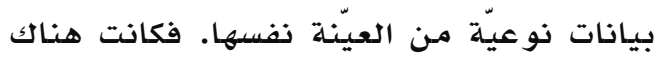

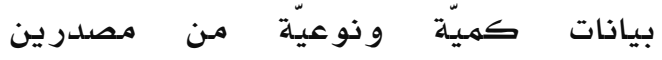

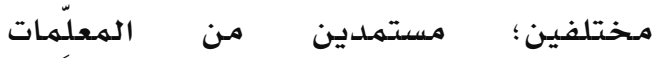

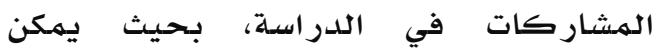

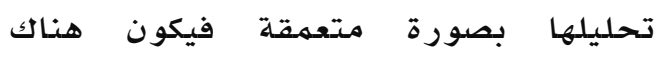

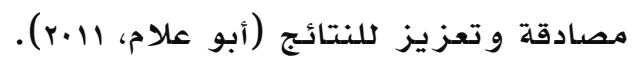

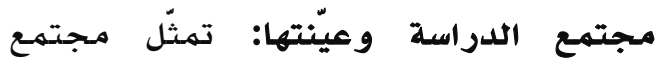

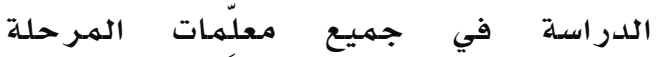

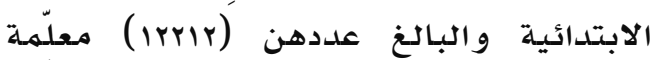

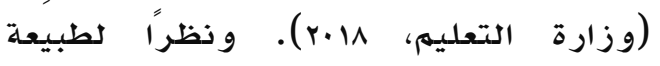

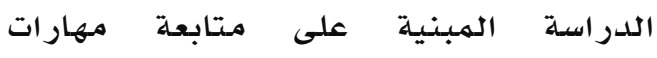

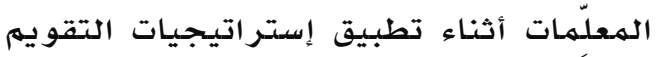


لقياس معارف المعلّمات حول التقويم من

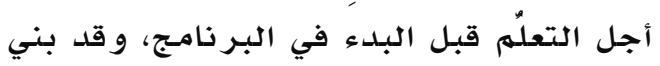

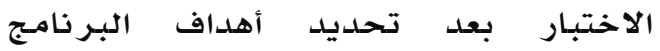

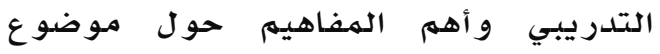

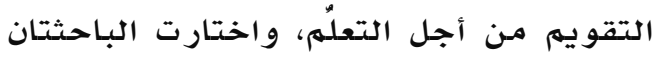

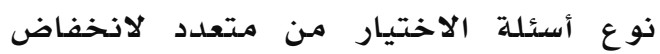
نسبة التخمين عند اختيار الإجابة (أبو علام، (r.ll). وتم التأكد من تكافؤ الاختبارين بتبديل وظيفتهما كاختبار قبلي وبعدي في

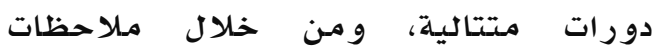
الهحكمين حول تكافؤ الأسئلة.

صلق الاختبار التحصيلي: تم تحكيم

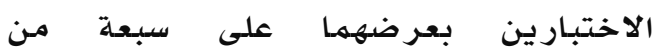
المختصين في العتليهم العلوم و القياس و التقويم للتأكد من صنديم صدهما و مناسبتهما للغرض الذي وُوضعا لقياسه، كما تم تحكيم

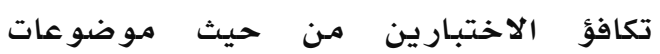

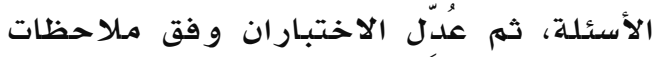

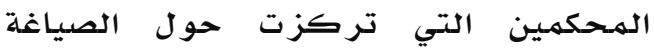
اللُغوية، و عدم تكافؤ بعض الأسئلة.

ثبات الاختبار التحصيلي: حسبَ الثبات باستخدام معامل الفا كرونباخ للنهموذجين

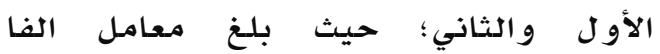

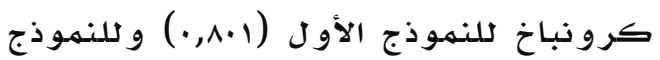

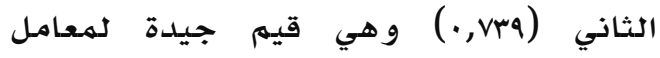
الثبات؛ مسما يشير إلى صلاحيلة الأداتين

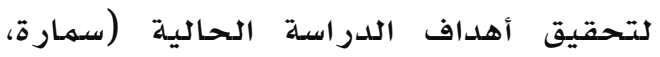
النهمر، و إبر اهيه، آهريق 1919). ثانيًا: الاستبانة المقنّنة المفتوحة: أُعطيَ جميع معِلّمات المدارس المشاركة

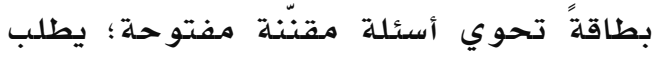

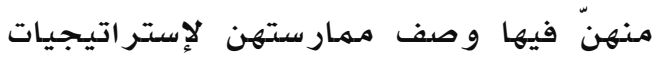

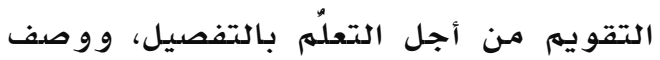

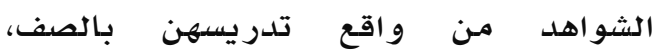

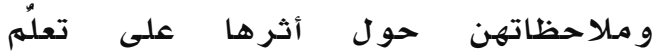
الطالبات، و على عملية التمن التدريس. الأسئلة

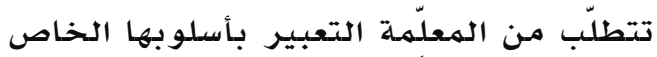

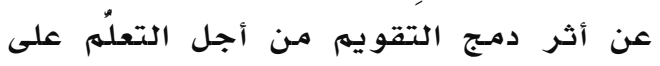

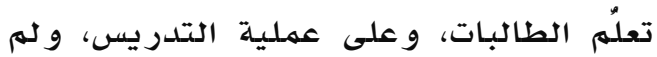

لتشهل (10V) معلّمهة، كما تم تدريبهنّ في فترات قصيرة على مدار الفصل الدرراسي، و تم تطبيق صورتين متكافئتين من الاختبار للتخلص مـن أثر الاختبار القبلي. و ولزيادة

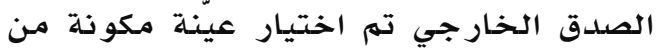

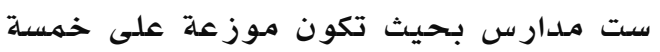
مكاتب تعليم مختلفة حتى مئى تكون العيّنة

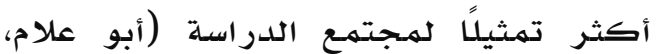
.$(r \cdot 1)$

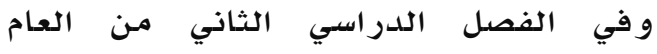

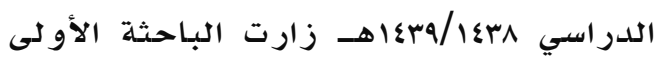
المدارس المشاركة ووزعت استبانة

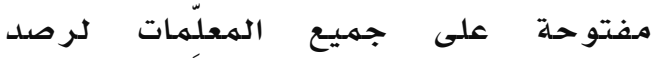

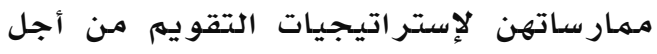

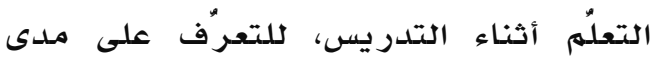
فاعلية البرنامج التدريبي في تطوير مهار اتهاء

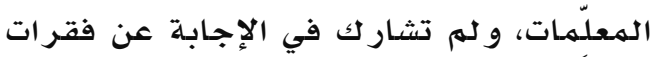
الاستبانة المفتوحة سوى و يوضح جدو ل العيّنة الدر اسلة. جدول المدارن بيانات عينة المدارس المشاركة في الدراسة

\begin{tabular}{|c|c|c|c|}
\hline عدد & عدد معلِّماتها & المكتب الإشرافي & المدرسة \\
\hline ir & r) & الحرس & 1 \\
\hline 17 & $r \varepsilon$ & الروابي & r \\
\hline 。 & iv & الثمال & r \\
\hline v & o. & وسط & $\varepsilon$ \\
\hline 7 & rt & الحرس & 。 \\
\hline 1. & r & البديعة & 7 \\
\hline • & $1 \varepsilon$ & معلِّمات مدارس أخرى & V \\
\hline 07 & $|v|$ & & المجموع \\
\hline
\end{tabular}

أدوات الدراسة

كتحقيق أهداف الدراسة، تم استخدام الأدوات

التالية:

\section{أونًا: الاختبار التحصيلي:}

تم إعداد نموذجين متكافئين مـن الاختبـار

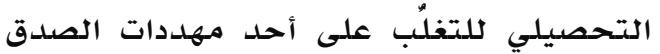

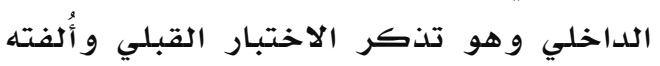

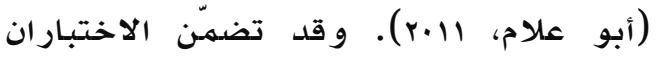
عشرة أسئلة من نوع اختيار من متعدد 
من الفشل. وشملت بقية الجلسات عرض أتصات

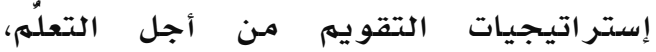

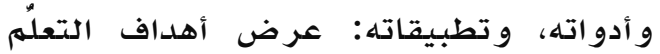

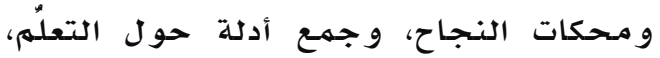
و التغذية الر اجعة، و التقويم الذاتي، وتقويم

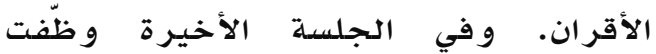

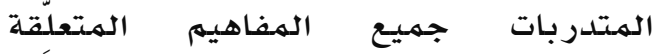

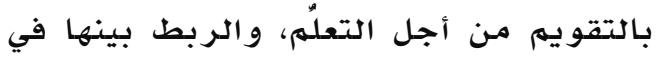

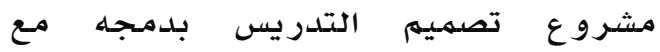
التقويم الصفي. انتهى البرنامـج بالتأكيد

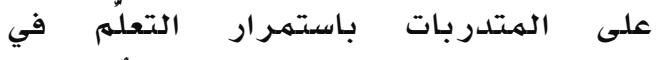
مدارسهن عبر تكوين مجتمعات تعلّم مهني داخل المدررسة أو الحي.

\section{إجر اءات ونتائج الدراسة}

الاطلاع على الهـراجـع الهـتعلّقة بالهـوضوع

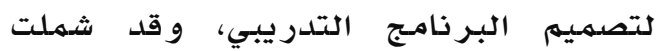

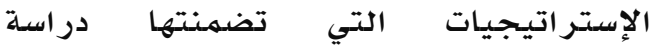

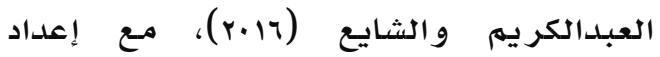
الأنشطة التدريبية لتحقيق أهداف البر نامـج. إعداد أدوات الدراسـة و عر ضها على مجموعة من المحكمين؛ للتأكد من صدقها الظاهري، و مناسبتها لقياس السهمة الهر اد قياسها، و تعديلها و فق توجيهاتهم.

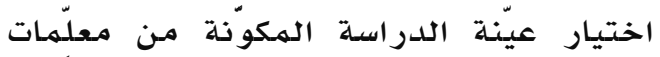

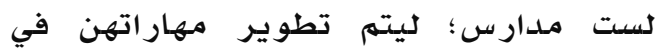

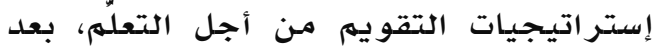

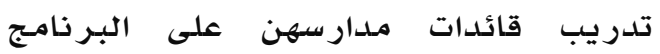

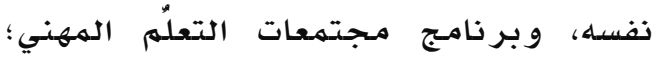

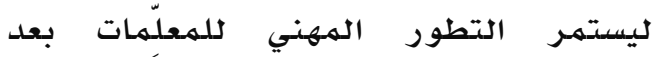

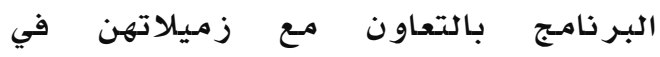

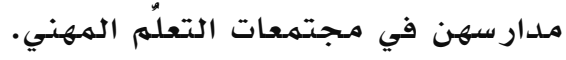
التطوير الههني لهعلّمات مـدارس العيّنة بإلحاقهن في ثماني دورات متتالية لهمدة ثلاثة أيام خلال الفصل الدراسي الثاني من

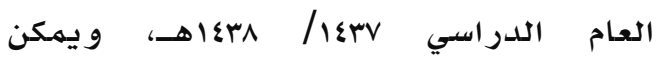
للمعلّمات بعد ذلك متابعة تطور أدائهما في

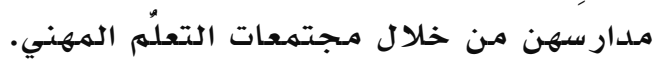

تتضهمنّ الاستبـانة أي أسئلة موضو عية

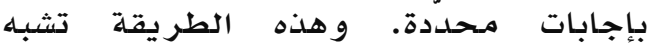

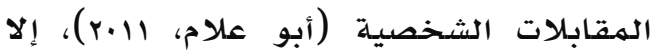

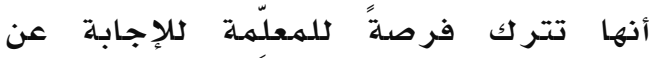

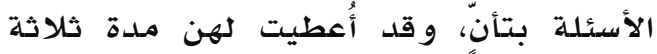

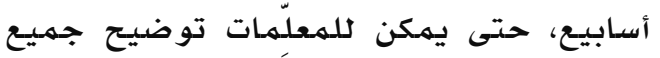

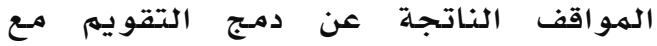

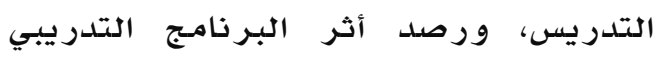
على تعلّم الطالبـات.

صدق الاستبانة المفتوحة: عُرضت الأسئلة

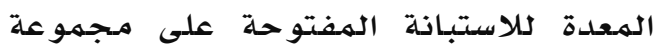

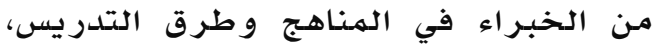

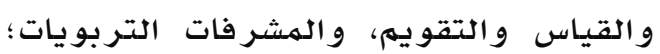

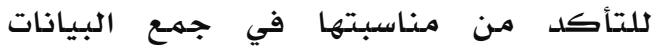
الكلازمـة لتطوير الأنموذج، وسلامتتها العلميلة

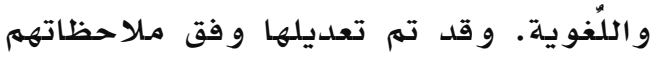

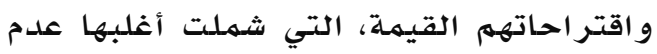
وضوح بعض العبارات، أو عدم سدلامتها احتها اللُغوية. تصوح

المصداقية: نظرًا لأن الاستبـانة المفتوحة

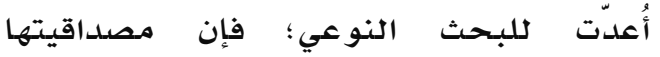
و موثوقيتها تتحقّق بتنوع الطرق و تعدّدها في جمـع البيانات، فإذا اتضح وجودود اتسـاق

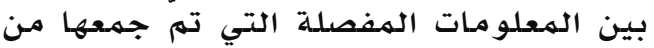

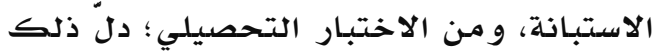

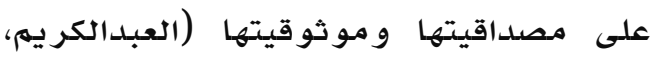
.$(r \cdot 1 r$

وصف البرنامج التدريبي: نفّت الباحثة

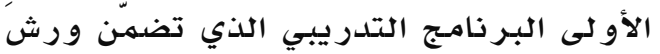
عملٍ تفاعلية في ست جلسات خلات خلات ثلاثة

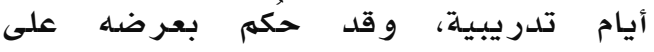

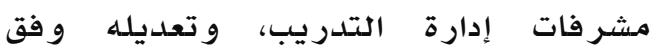

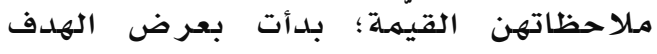

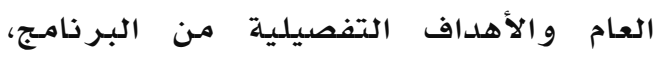
و توضيح مفهوم التقويم من أجل التعلّه،

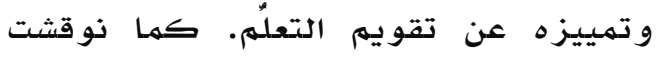

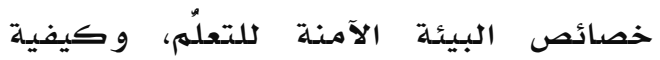

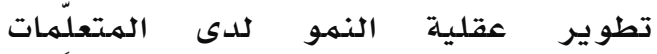

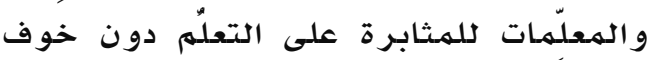


اقتصرت الهشاركة في الإجابة عن أسئلة

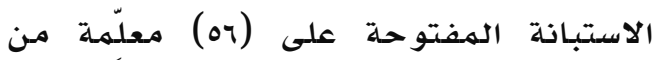

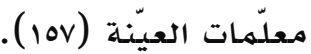
للإجابة عن سؤال الدراسـة الذي نص على:

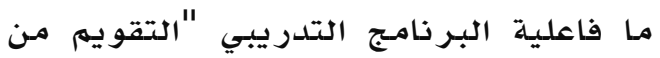

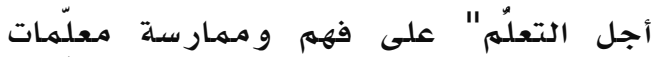

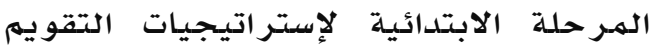

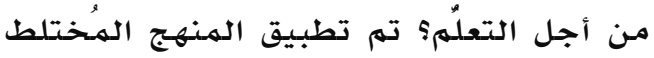
المبني على الاستعانة بطرق بحث كميّة

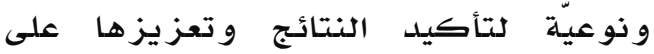
النحو الآتي:

أونَا: الطريقة الكميّيّة: ته حسـاب المتوسطات

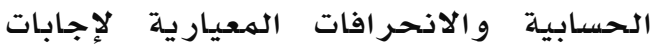

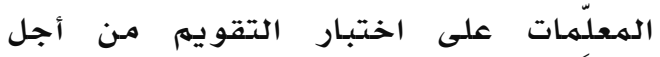

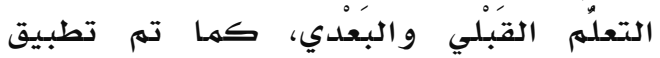

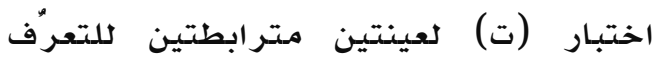
على دلادلة الفروق بين المتوسطين

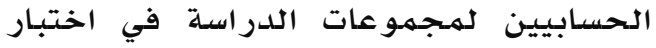

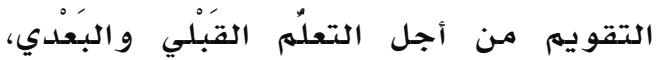

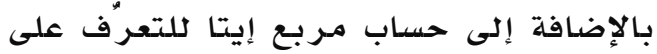
حجم وفاعلية البرنامسج التدرريبي، وسيتم

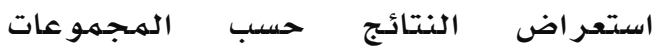

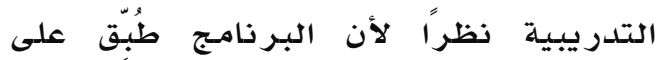
ثماني مجموعات تدريبية، كل مجمموعة تم تدريبها بشكل مستقل جدول ولهو

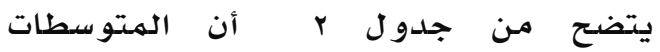

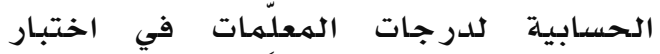

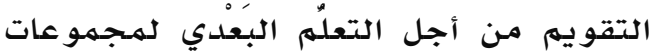

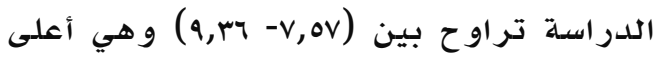

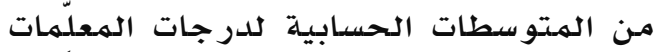

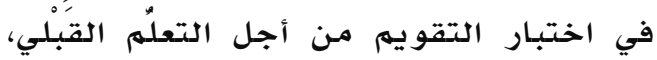

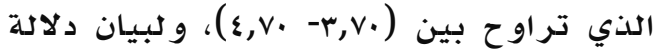
الفروق بين متوسطي درجات معلِمات كل

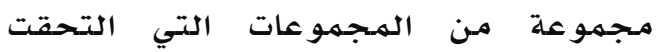

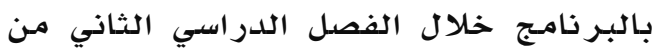

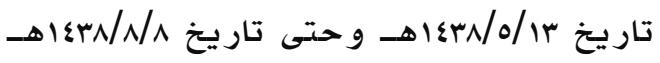

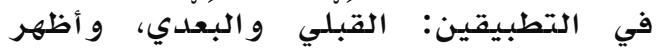

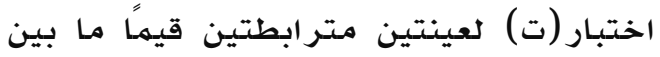
(10,19-0,V9)
تطبيق الاختبار القبلي في بداية كل كاء كاء برنامـج تدريبي، ثم تطبيق الاختبار الهكافئ

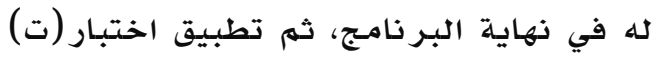
للعينات الهتر ابطة للتعرف فلى على مدى فاعلية

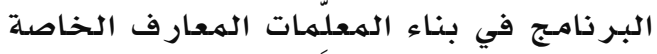
بالتقويم من أجل التعلِّمَ.

إتاحة ما لا يقل عن أربعة أثهر من

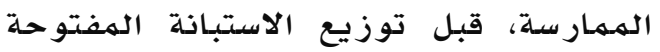

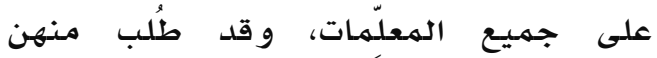
الإجابة عن الأسئلة بالتفصيل، مـع توضيح

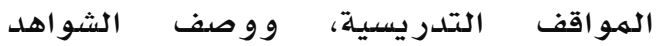

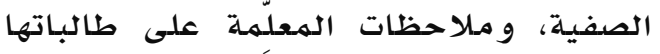

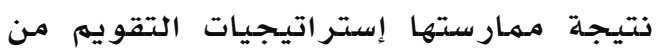

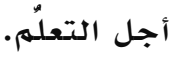

التحليل الكيفي للبيانات والمـلاحظات

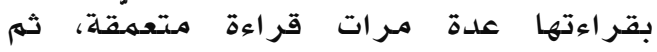

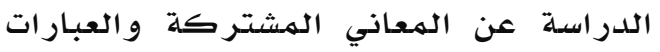
المتشابهة، ومن ثم ترميزها وتصنيفها في

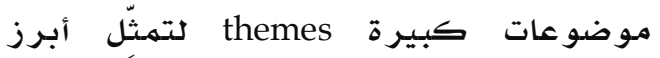
تأكيدات الدراسة وذلك لـوإجابة عن سؤال الدر اسة و الخرو ج بالتو صيات. المعالجات الإحصائية: مُعامل ألفا كرونباخ لقياس ثبات الاختبارين التحصيليين. اختبـار (ت) للعيّنات الهتر ابطة للتعرِف على

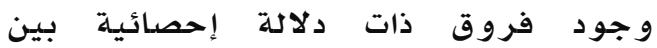
متوسطات درجات المعلمِمات في الاختبـار

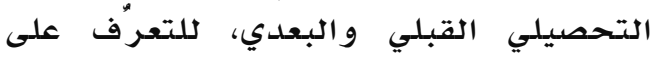
فاعلية البر نامـج في تطوير معار ف المعلّمـات

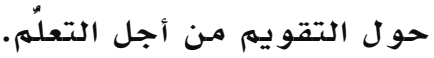
نتائج الدراسة لهم تلاحظ الباحثة الأولى أثرًا و اضحًا

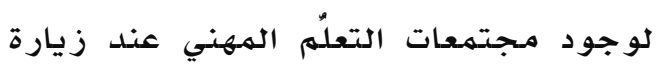
مدارس العيّنة في الفصل الدرواسي الثياني

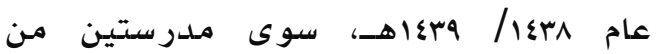

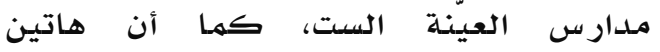
المدرستين اقتصر نصيب بر نامسج التقويم التهارئ

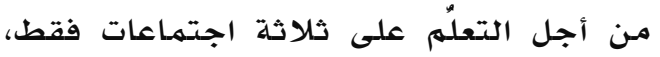

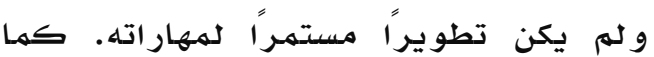




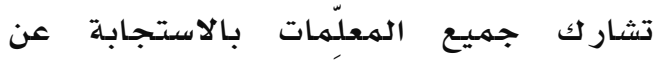
الاستبانة المفتوحة، كما لهم تجد الباحثتان

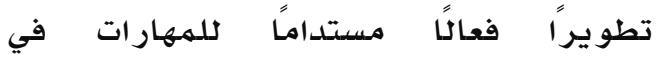

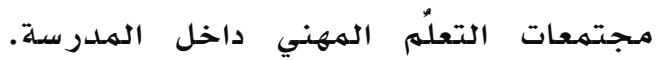

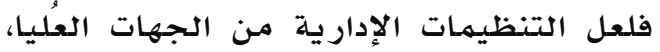

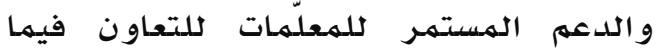
بينهن داخل المدرسة أو الحيّ في مجتهر التمعات

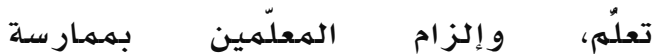

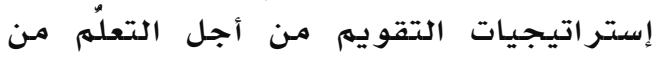

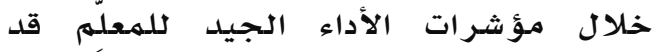
يساعد على اهتهمامهن بلدمجها مـع التدريس .(Koh, et al., 2015)

ثانيًا: الطريقة النوعية: تم تحليل البيانات

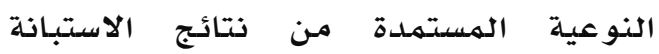
المفتوحة و أظهرت نتائج التحليل الكيفي

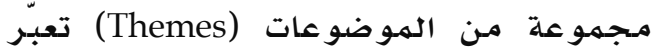
عن تأكيدات الدر اسلة (Assertions):
الدلادة (1.,.)؛ مـما يدل على وجود فروق

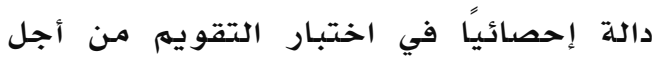

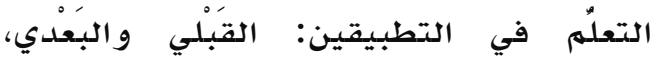

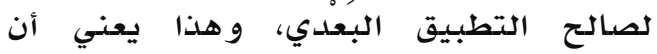

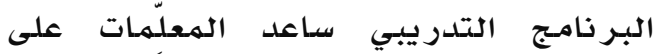

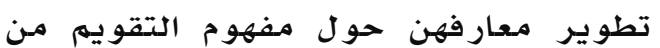
أجل التعلّمر و إستر اتيجياتهـ. كما يتضح من الجدول أن حجم التأثير

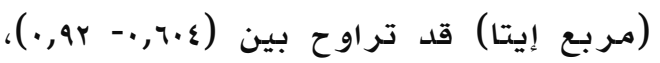
وهي حجوم تأثير كبيرة إنساً

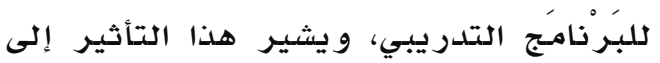

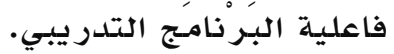

وبالرغم من أن الفهم العميق للتقويم

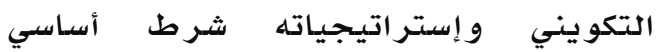

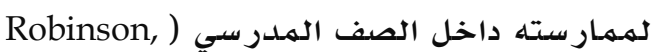

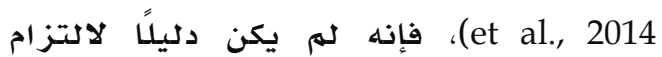

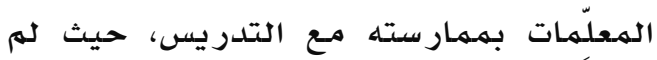
جدول r

متوسط درجات الاختبارين القبلي والبعدي لجميع المجموعات، والانحرافات المعيارية، وقيمة (ت) للعيّات المترابطة، ومستوى الدلالة، وقيم

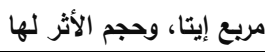

\begin{tabular}{|c|c|c|c|c|c|c|c|c|}
\hline الأثز & قيمة مربع & الدلالة & قيمة ت & الحرية & الانحراف & الحسابي & الاختبار & الناريخ \\
\hline كبير جدًا & • & $\cdot, \cdots$ & $1 \cdot, r r$ & r & $\begin{array}{l}1, r\} \\
r, 19\end{array}$ & $\begin{array}{l}\varepsilon, \leqslant 7 \\
\wedge, \vee q\end{array}$ & البَالَبَلِي & $0 / 11$ \\
\hline كبير & $\cdot, V V$ & $\cdot, \cdots$ & 1,09 & rr & $\begin{array}{l}1,47 \\
1,90\end{array}$ & $\begin{array}{l}r, v . \\
\gamma, O V\end{array}$ & البَبَبَلِي & $0 / r$. \\
\hline كبير & $\cdot, T$. $\varepsilon$ & $\cdot, \cdots$ & $0, \vee q$ & rr & $\begin{array}{l}1, r 4 \\
1, \mathrm{r} A\end{array}$ & $\begin{array}{l}\varepsilon, \vee \cdot \\
\vee, \vee \wedge\end{array}$ & البَعْدبي & $0 / K V$ \\
\hline كبير جدًا & $\cdot, q Y$. & $\cdot, \cdots$ & 10,19 & $r$. & $\begin{array}{l}1, \cdot 1 \\
1, Y r\end{array}$ & $\begin{array}{l}\varepsilon, \varepsilon \wedge \\
q, \cdots\end{array}$ & البَعْدبِي & $T / \varepsilon$ \\
\hline كبير جدًا & •, Nor & $\cdot, \cdots$ & $1 \cdot, \lambda$. & $r$. & $\begin{array}{l}1, \vee . \\
\cdot, 7 \wedge .\end{array}$ & $\begin{array}{l}\varepsilon, \cdots \\
\wedge, \wedge)\end{array}$ & البَعْدِي & $v / r$ \\
\hline كبير جدًا & $\cdot, \wedge ৭$. & $\cdot, \cdots$ & $1 r, \cdot r$ & rI & $\begin{array}{l}\cdot, 904 \\
1, r \text { r }\end{array}$ & $\begin{array}{l}\varepsilon, \varepsilon) \\
9, r q\end{array}$ & البَعْدِي & $v / 1$. \\
\hline كبير جدًا & $\cdot, 91 \mathrm{~V}$ & $\cdot, \cdots$ & $1 \varepsilon, \cdot V$ & 11 & $\begin{array}{l}1, \varepsilon r \\
1, .0\end{array}$ & $\begin{array}{l}\varepsilon, \varepsilon V \\
q, \Gamma)\end{array}$ & البَعْدِي & $V / r \varepsilon$ \\
\hline كبير جدًا & $\cdot, 190$ & $\cdot, \cdots$ & $1 T, \cdot 9 V$ & IV & $\begin{array}{l}1, \varepsilon r \\
., 9 \vee 9\end{array}$ & $\begin{array}{l}\Sigma, r Y \\
\Lambda, T)\end{array}$ & البَعْدِي & $\wedge / \wedge$ \\
\hline
\end{tabular}


حيث أصبـحت كل طالبـة تحاول المشاركة

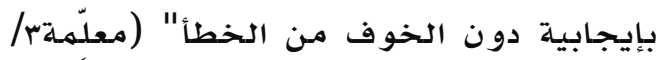

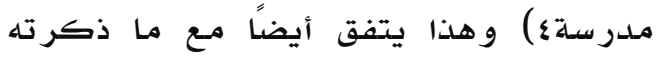

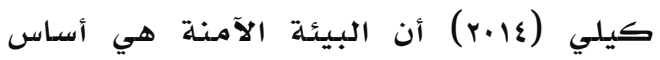

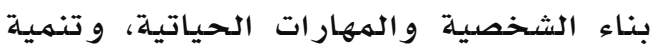
المهار ات الإبلداعية.

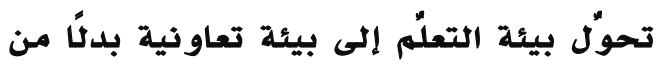

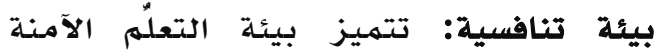
بتوفر التأمل والحوار بين الطلبـة، كما تشجعهم على المشاركة في النقاش الصفي ضمن مجمهوعات تعاونية. و في هذه البيئات

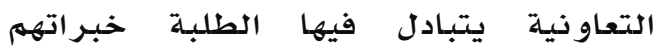
وتجاربهم، مـما يجعل الطلبة مصادر تعلّم

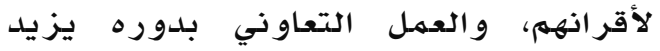

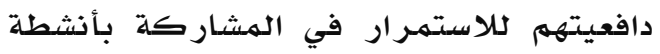

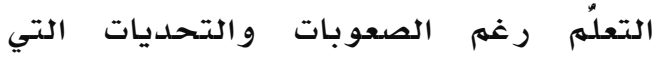

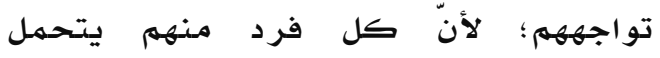

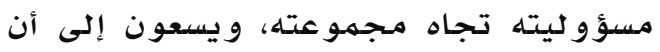

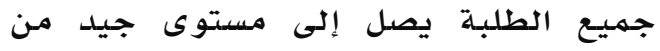

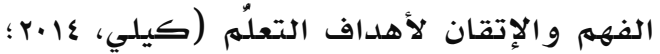

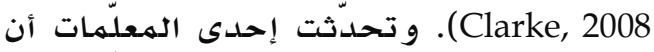

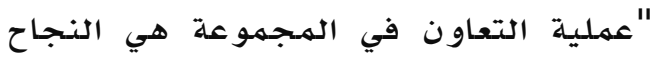
بذاته، و أذهم يسعون على الفهم و الشرح قبل

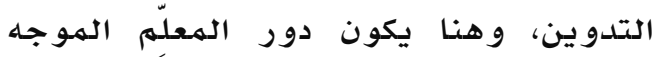

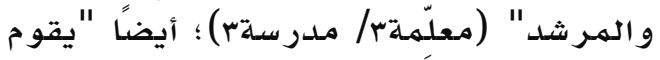
الطلاب بتصحيح إجابات بعضهم البعض بناء

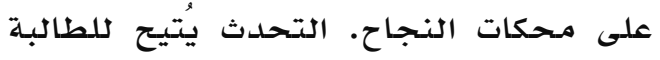

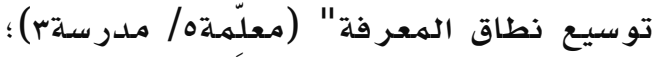
كما "ساعدت عملية التعاون بين الطالبات

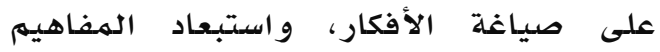

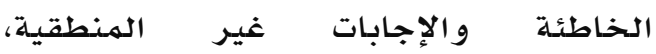

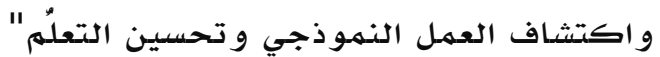

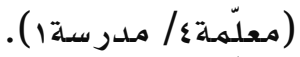

و تُتيح الهعلّمات تبادل الخبرات بين الطالبـات من خلال الأزواج التعاونية حيث يتم تبادل

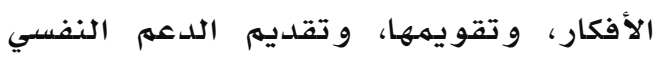

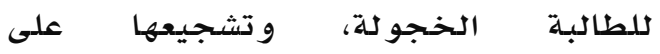
المشاركة، وبذلك يساعدهن في تحسين

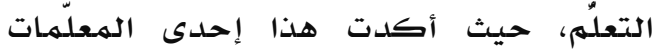
بقولها "مههم عمل الطالبات في أزواج
البيئة الآمنة للتعلّم: وصفت المعلّمسات البيئة الصفية بأنها بيئة مريحة يحة للتعلهم تُنهمى فيها

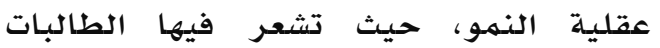

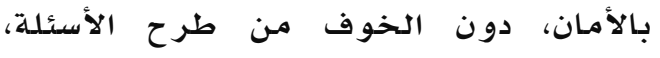
ودون الخوف أو التردد في الإجابة عن

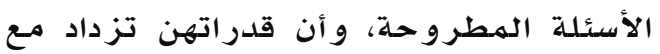

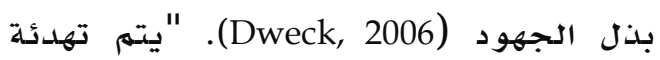
الصغيرات وبعث الطمأنينة في أنفسهن، و أنهن في مرحلة تلدريب وتعلّم فلا داعي

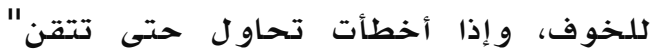

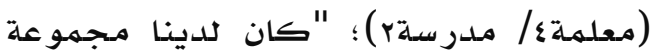
من الطالبات لديهن خجل أو خوف في طرح

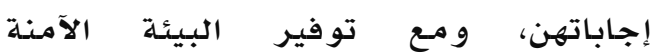

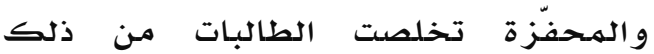
و أصبحنَ قادرات على الإجابة بطر يقة جيدة،

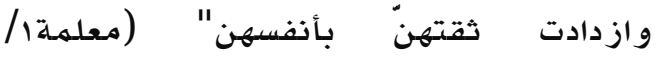
مدر مسةr).

و تتضسح أهمية البيئة الصفية التي تشعر فيها

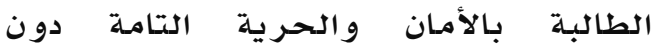

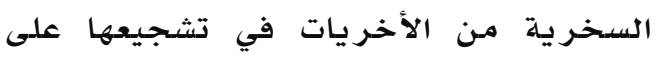

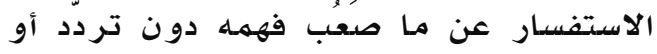

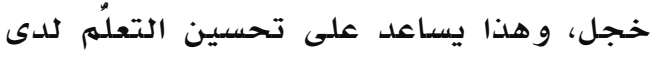

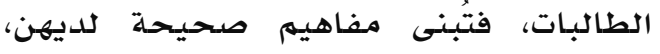

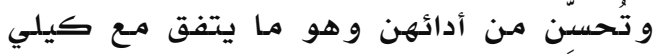

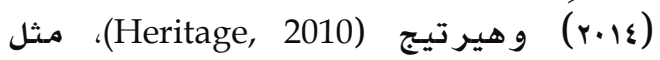
"لدى بعض الطالبات في الصف الثالث

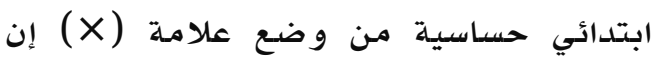

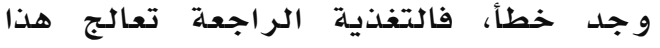
المـوضوع، و تسـاهم في تحسين مستواها مـن

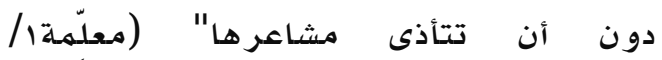
مدرسة|)؛ "دونجب أن تعرف الطالبـة أنها

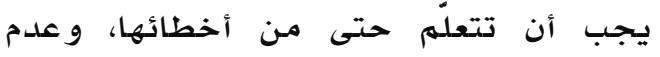

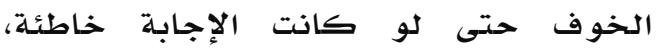

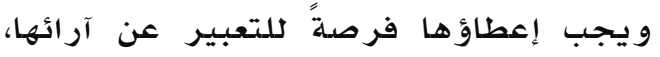

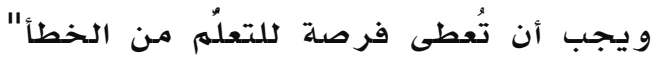

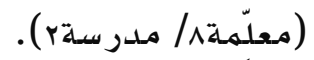

وكتبت إحدى المعلّمات عن أثر البيئة

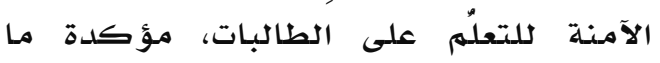
و صفته كلارك (Clarke, 2008) فقالت: "أثّر ذوفته تأثيراً إيجابيًا على الطالبات 
مدررسةه) ووتتفق هذه الثقافة مـع مـا أكّد عليه بالاك وو ليام (Black \& Wiliam, 1998)، مدونه

و كذلك دو يك (Dweck, 2006). تنمية مهارات التفكير: غيّرت النظرية

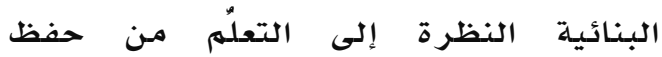
و استظهار ونقل للمعارف، إلى عمليات عقلية نشطة تستند على مهارات التفكير الأساسية، و التفكير الناقد، والتفكير الإبداعي، والقدرة

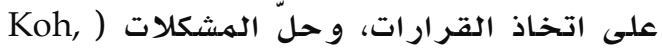

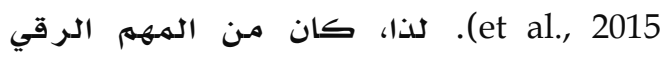

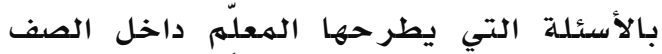

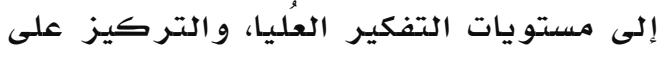
الأسئلة المفتوحلة التي تتيح الفر صدة للتعبير

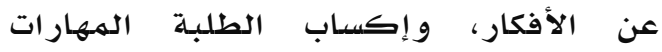

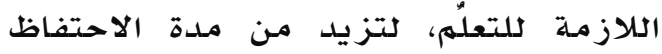
بالهعارف و المهارات، و لجعلها أكثر فائدة لحياة الطلبة (Harlen, 2003; Crooks, 1988).

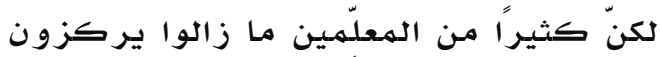

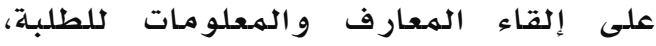
و الاكتفاء بالدور السلبي للطلبـة بالاستماع و تدو ين الملخصات (Fayadh, 2017).

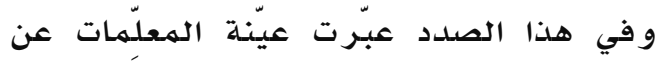

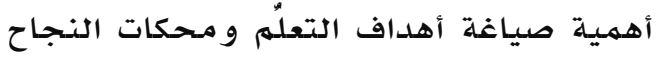

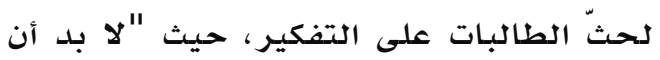

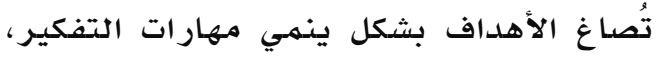

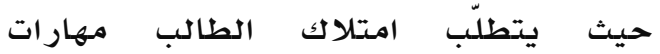
كالتخطيط، اتخاذ القرار، ...، إلت. فحينها

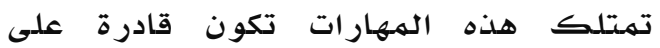
خوض مجالات التنافس في هذا العصر

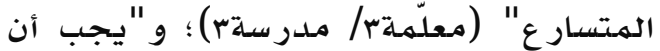

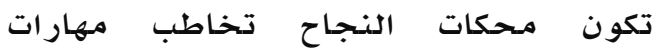

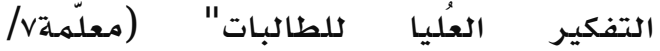

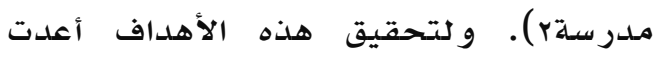

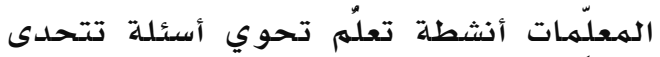

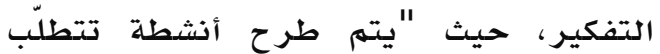
التفكير الناقد، و العصف الذهني، والتعبير

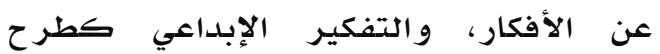

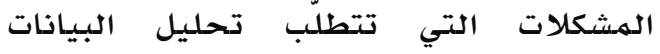

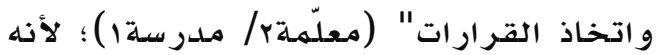

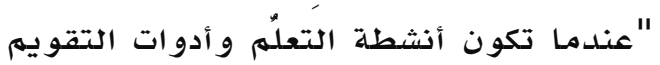

تعاونية لأنه بجعل كل طالبة تشارك وتبّدي رأيها، ويكون هناك تعاون وتشارك

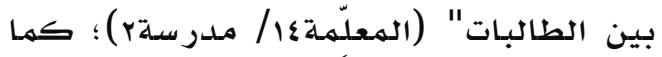
أن "كل طالبة ضعيفة تحتويها طالبة

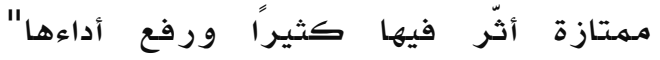

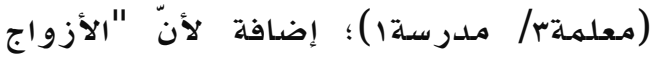

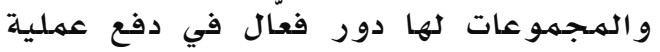

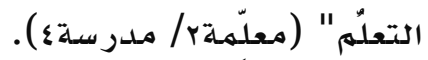

كما وجدت المعلّمات فائدة في تبادل أعمال

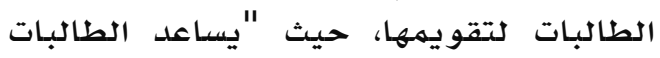
في معرفة عدد كبير من الإجابات، وفي

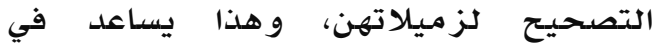

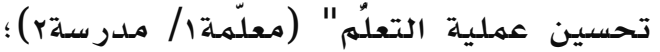
و "يتهم تبادل أعمال التلميذات لتقويمها وفقل

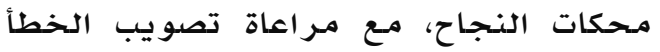
و تصحيحه وغلق الفجوة، وتعزيز إجابات

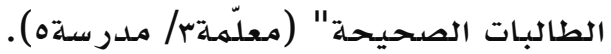
و تتتنمّى المهارات الاجتماعية، مثل: التعاون، و احتر ام آراء الآخرين وتقدير هـا مـن خلال

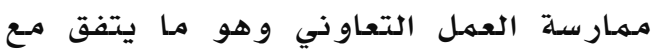

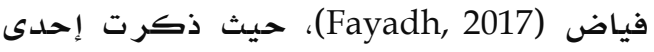

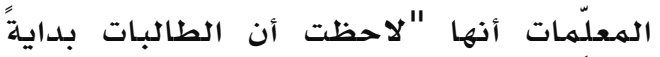
كان تفكير هم سطحيًا و كل طالبة تستأثر بر أيها، ومسع مرور الأيـام أصبـحت الطالبـات

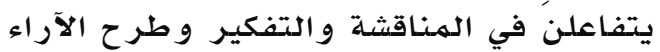

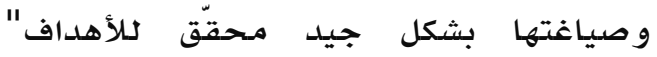

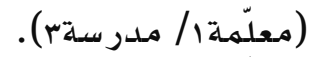

و يسـاعد إلغاء ثقافة التنافس بين الطالبات على نشر ثقافة التعاون، مـما يزيد فاعليد

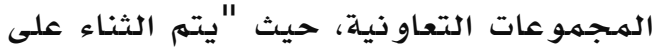
الأداء و ليس على ذات الطالبة بحيث لا يكون

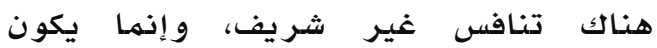
التعزيز لكلأداء فقط فيعطي دافعية أكبر

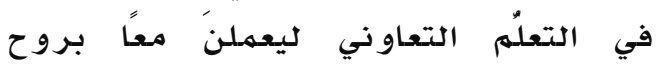

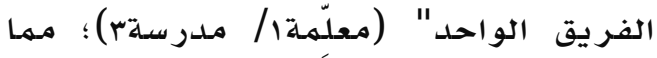
حث" المعلّمات على تفعيل المبجمواحمات ورهو

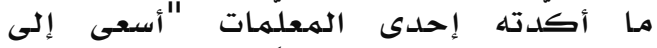

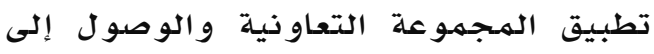

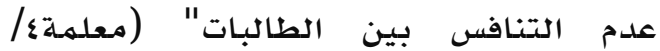


بمحكات النجاح الخاصة بالدرس" (معلّمةل/

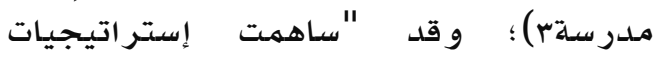

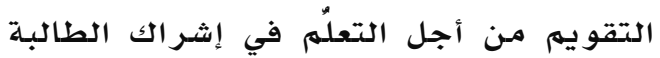

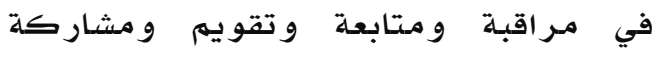

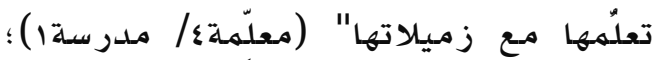

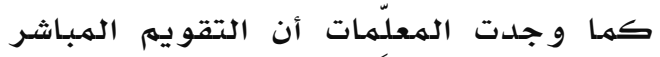
للأنشطة يعطي نتائج جيدة ويحسنّ أداء الطالبات، حيث "من خلالها تتحسن عملية

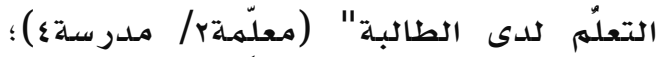

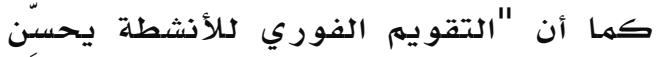

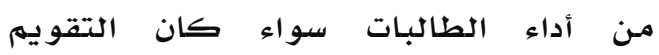

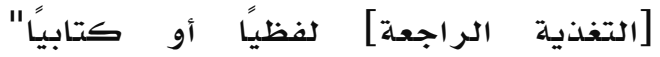

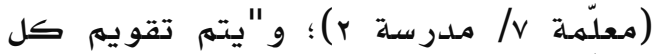
جزء من قبل الطالبة مباشرة، وعدم تأخيره

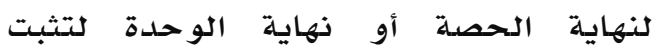

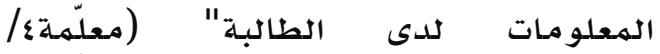

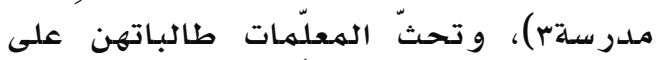
التحسين المستمر لكلأداء بعد تلقي التغذية

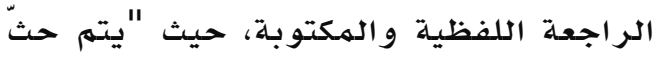

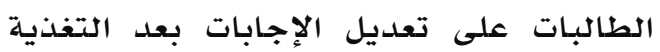
الراجعة ليتم تحسين التعلُم فيُكسب لعبل

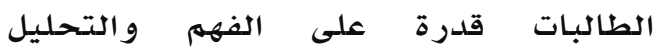

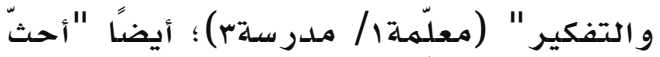
الطالبة على الاستفادة من التغذية الراجعة

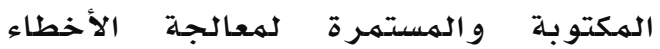
الشائعة و التصورات البديلة وربط المفاهيم

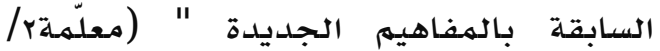

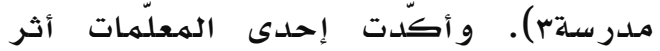

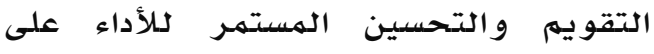

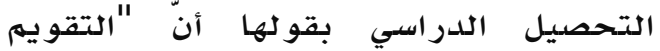

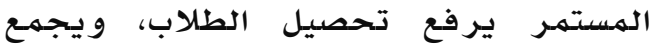

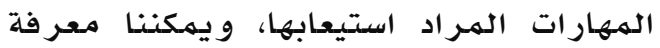
نقاط أو مواطن الضعف أو الخلل في سيره

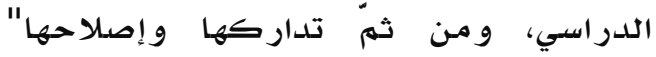

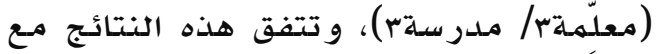
Black \& ) ما توصل إليه بلاك ووليام .(Wiliam, 1998

بناء الشخصية وتنمية مهارات حياتية: تسعى المؤسسات التربوية إلى تغيير مفهوم

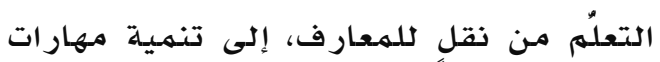

ذات مستويات تفكير عُليا ومفتوحة فإنها تقيس عمق الفهم لدى الطالبات؛ ليته

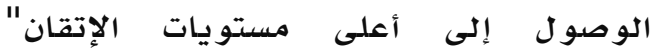

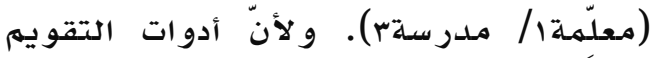
يجب أن تكون على توافق مـع الأهداف

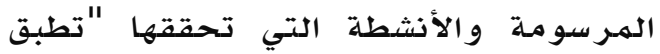

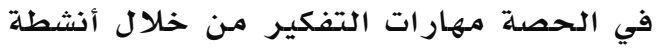

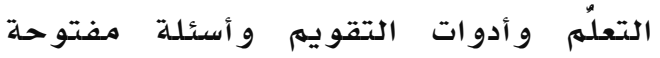

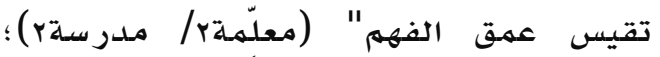

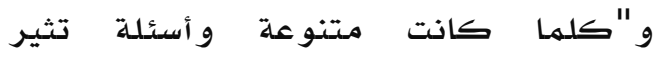
التفكير كانت أدوات التقويم والأنثطة

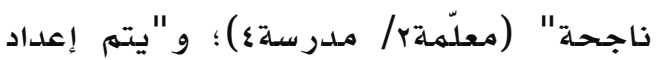
أدوات تقويم متنوعة وشاملة ذات أسئلة تقيس مدى فهم الطالبة بطريقة مفتوحة لا تحد من إجابة معينة، بل تترك لك للطالبة لطية

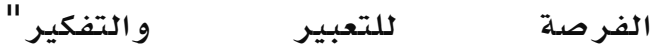

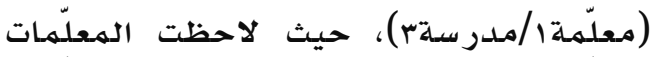

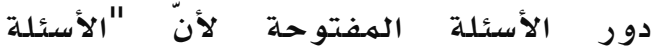

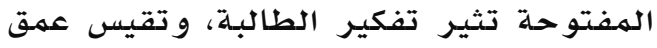

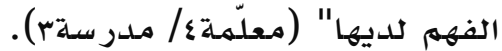
المراقبة الذاتية والتحسين المستمر للتعلّم: ددّت الدراسات أن حثّ الطلبة على التأمل التهل

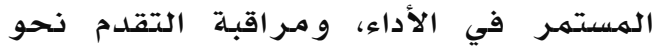

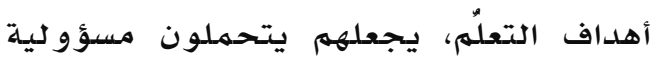

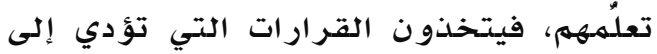

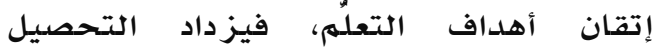

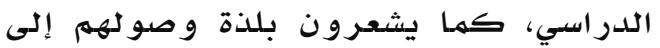

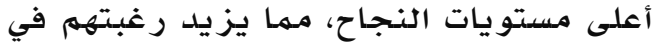

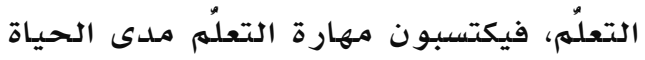

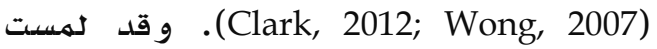

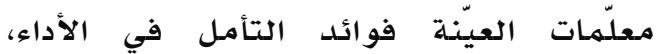

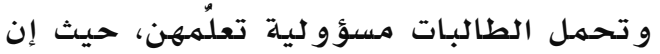

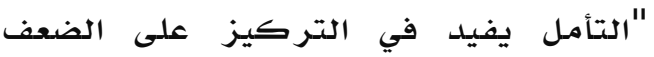

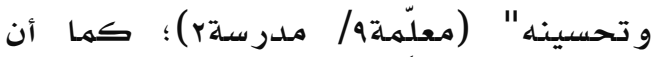
"التقويه يجعل الطالبات يتحملن مسؤو لية

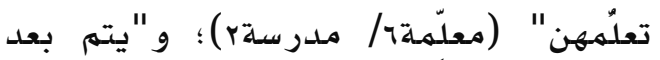
انتهاء إجابات الطالبات عمل تغذية راجعة بعد مقارنة مدى جودة أعمال الطالبات و معرفة مدى تحقق محكات النجاح. و تقوم

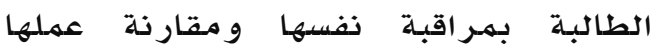




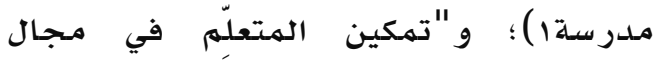

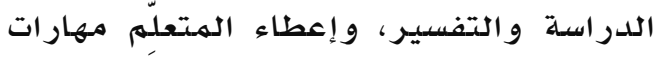

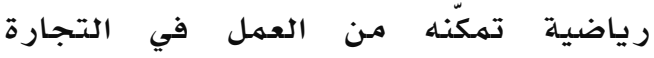

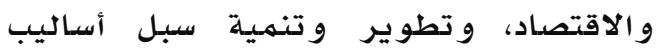

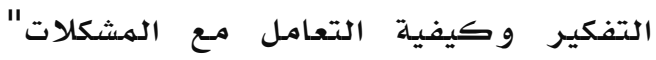

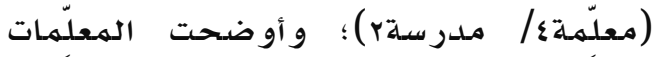

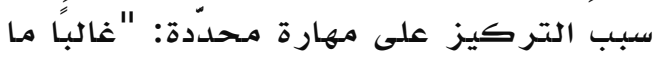

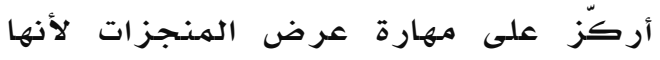

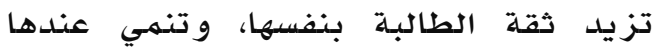

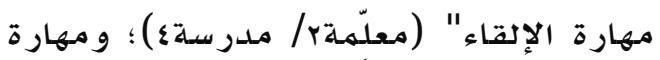

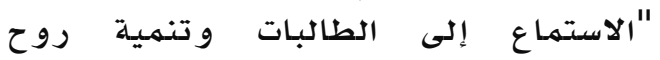

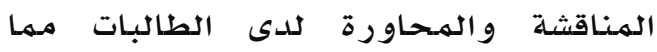

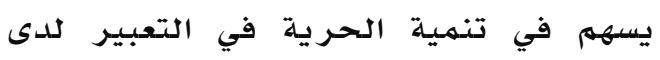

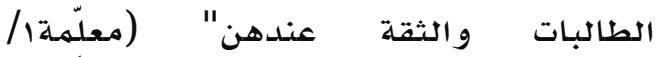
مدرسةه). و لا شك أن إستراتيجية التقويم

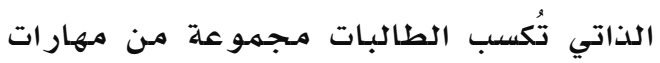

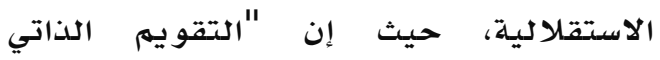

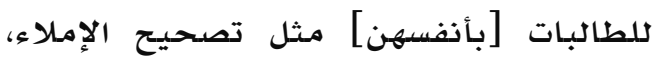

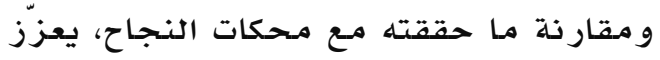

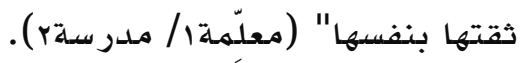

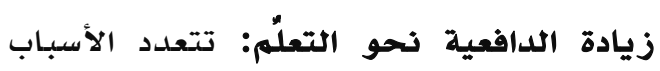

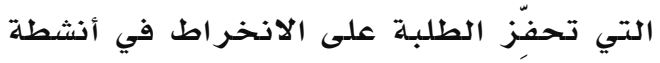

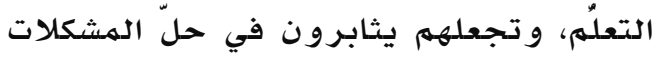

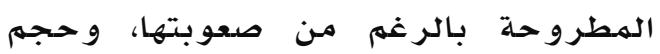

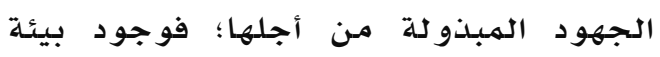

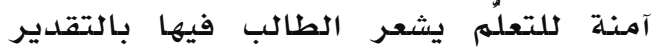
لأفكاره دون السخرية منها من قبل المعلّمِ

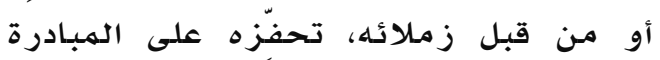

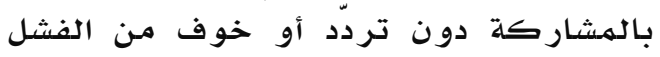

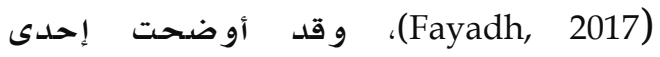

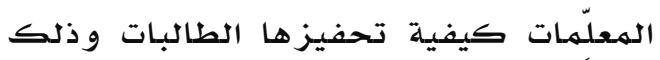

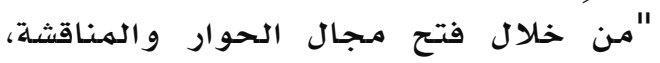

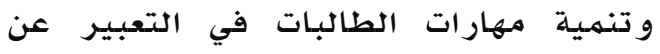

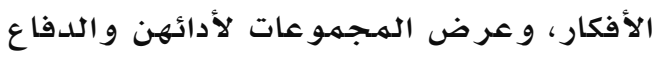

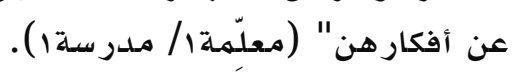

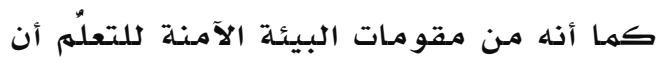

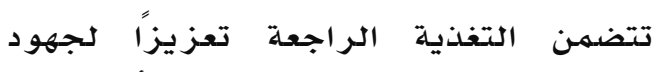

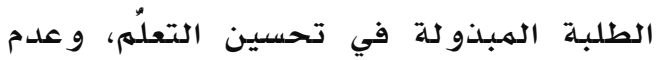

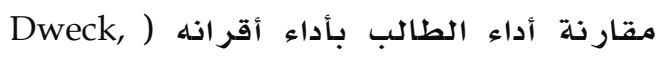

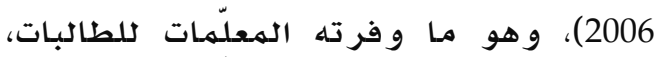

التفكير العُليا، وتنمية مهارات حياتية تؤهلهم لسوق العمل؛ كالتفكير الناقد،

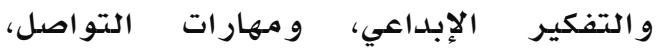
والتعاون، التي أُطلق عليها مهارات التهات القرن التهارن الحادي والعشرين لأهميتها في مساعدة التهات

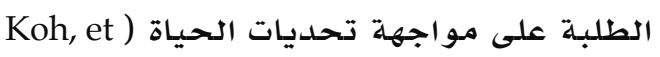

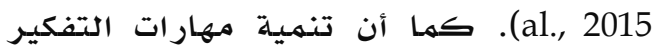
فوق المعرفي، والتأمل المستمر في الأداء، يجعل الطلبة يشاركون في عملية تقويم التهاء

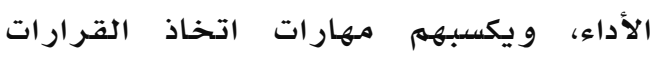
الجيدة التي تؤدي إلى مزيد من الاداء النجاحات،

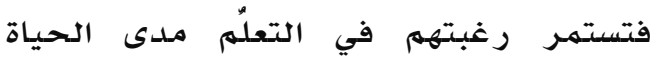

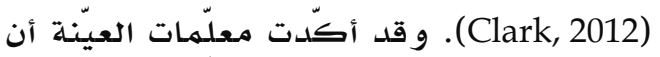

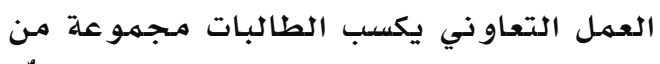

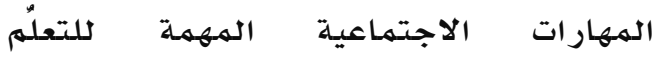

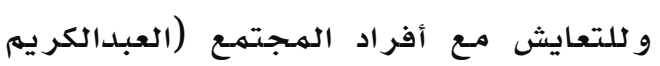

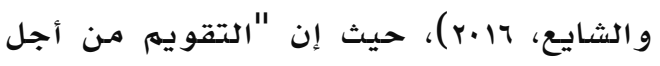

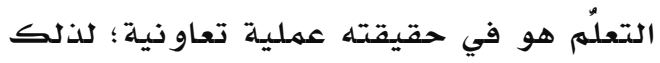

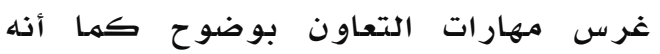

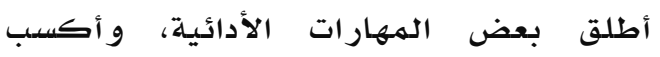

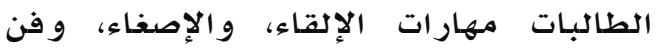

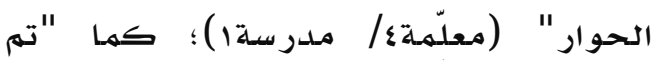

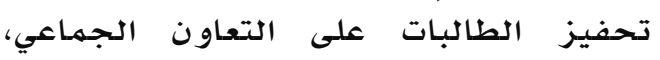
وشرح الأفكار و تبادلها، وإعانة صاحباتهن التهاون التهاتيز

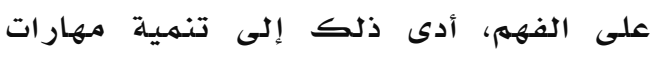

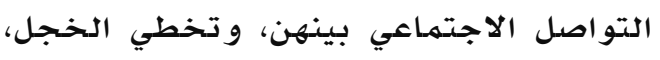

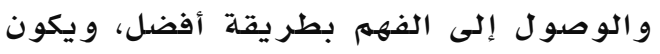

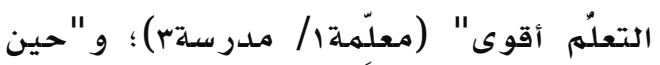
يكون الطالب في مكان لتقويم عمل زميل له الهوله

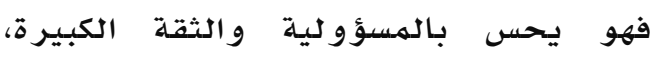

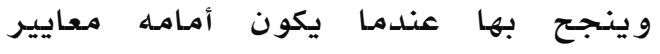

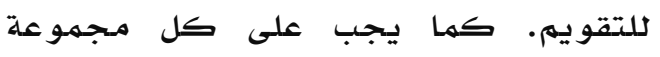

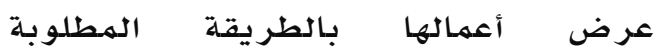

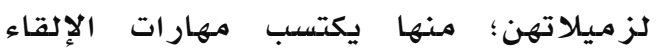

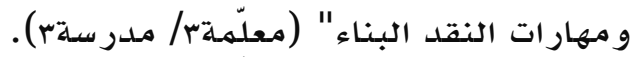
وتوضح بعض المعلّمات أهمية إعداد أنشطة

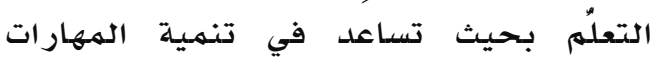

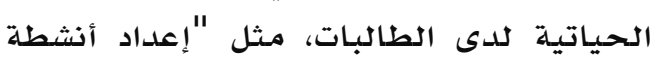

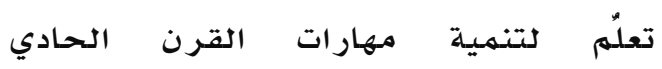

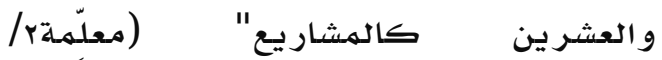


مدرسةب)؛ و "أنشطة التعلّم تحقق أهداف

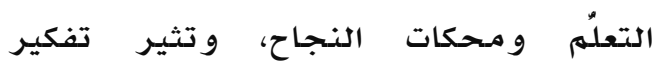

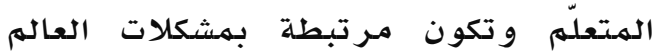

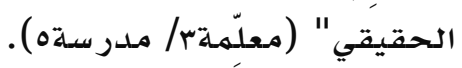

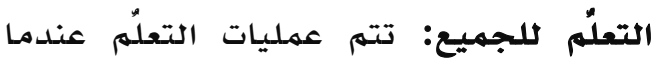
يكون المتعلّمون مشاركين و متفاعلين مـع

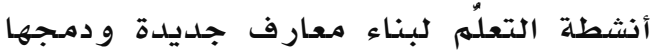

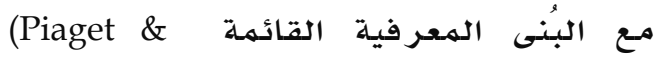

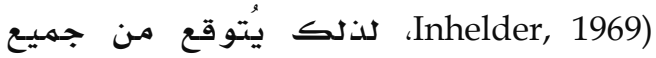
الطلبة على اختلاف مستوياتهم التحصيلية أن يكون لديهم مـراقبة ذاتية لبناء المفاهيه

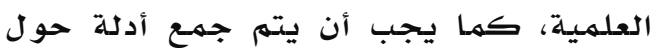

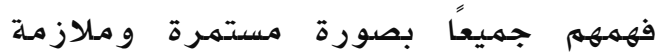
للتدريس، وأن يتم تقديم التغفذية الر اجعة التي ترشدهم جميعًا نحو تحسين التعلّم.

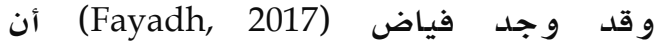
المعلِّمين يركزون على على تحسين أداء الطلبـة ذوي التحصيل المرتفع أكثر من الاهتهمام بالطلبة ذوي ذالتحصيل المنـخفض الذين

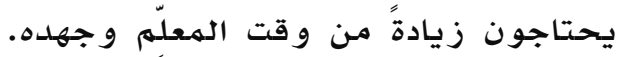
وتوضح معلّمات العيّنة دور أهمية الاختيار

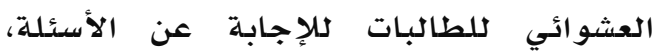

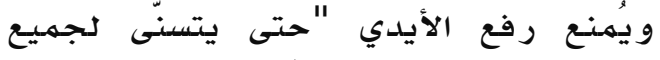

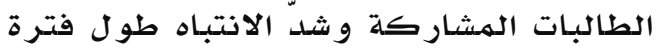

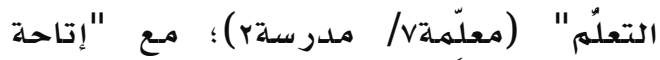
الفرصة لجميع الطالبات للمشاركة أثناء

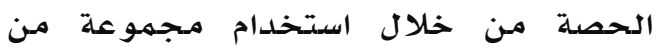

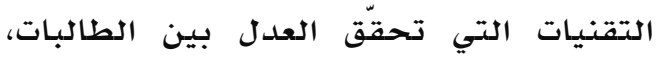

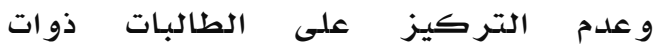

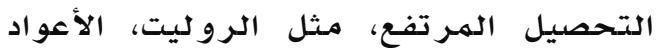

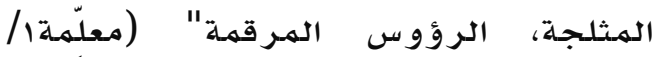

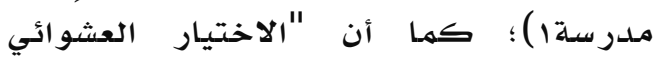

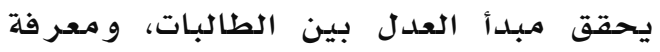

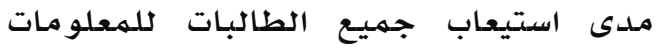
المقدمة لهن حتى يكون الجميع في مرحلة

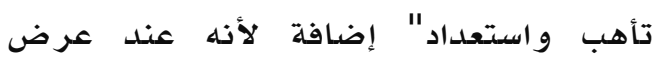
المشروعات أمام الصف "تشعر الطالبات

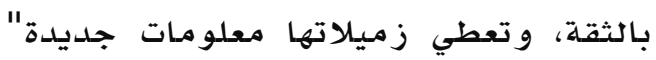

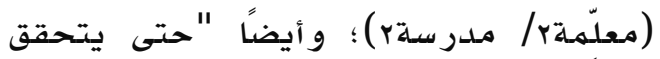

حيث "من خلال التغذية الراجعة للطالبة

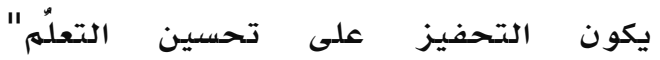

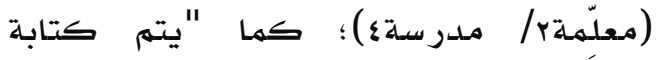
عبارات التغذية الراجعة بحيث تُبين نقاط نقاط القوة والضعف، و الثناء على الأداء بطريقة

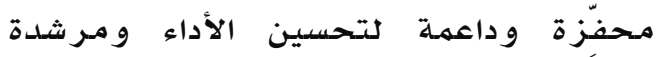

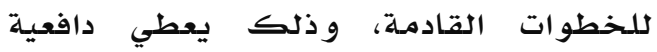

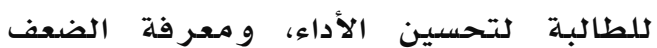
لديها بنفسها، ومعرفة مواطن القوة أيضًا

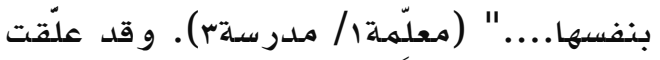
إحدى المعلّمات حول أهمية تركيز المهات الثناء

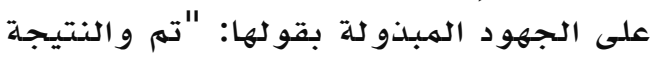

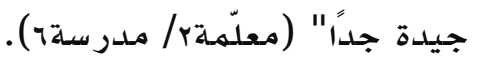

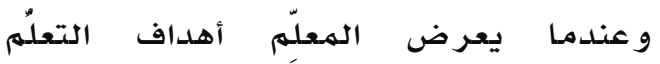

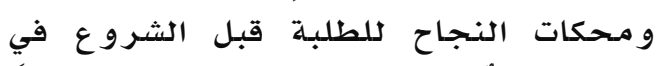

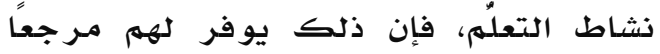

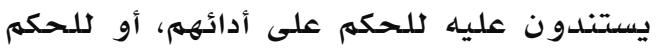

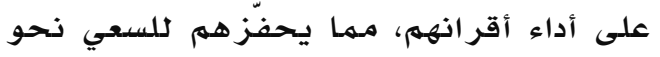

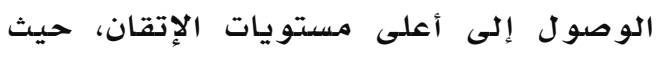
"يتمم عرض الؤول الأهداف في لوحلة ماثلة أمام

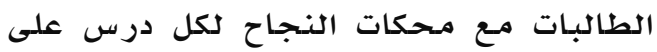
حدة، بحيث تكون الأنشطة ذات أهداف

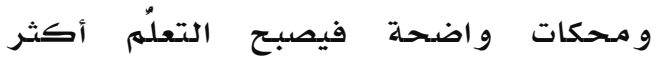

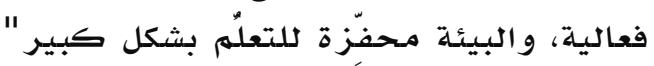

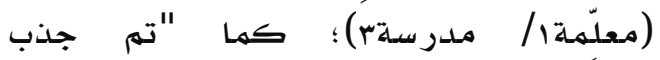

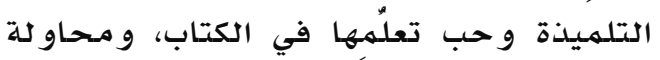
حلّ الأنشطة بمفردها أكثر من اعن اعتمادها

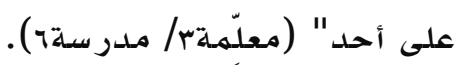

و من الأسباب التي تجعل التعلّم أكثر

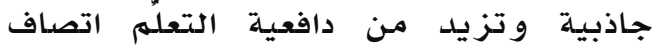

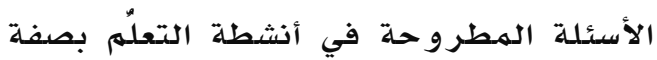
التحدي التي تثير تفكير الطلبة، وارتباطها

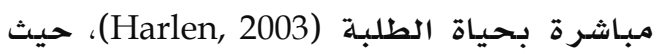
إن "مناقشة واستثارة مهارات التفكير العُليا لدى الطالبات يجعلها [الطالبة]

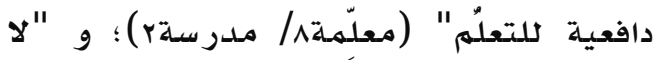
بلد أن تتنوع الأنشطة بحيث ترتبط

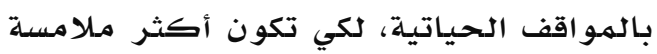

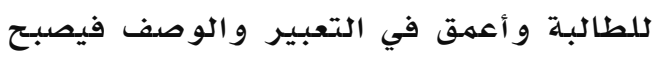

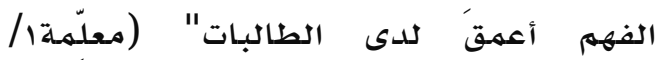


بدوره أدى إلى تحسين تعلُمَ الطالبات ووفقًا لما لاحظته المعلّمات.

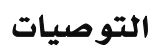

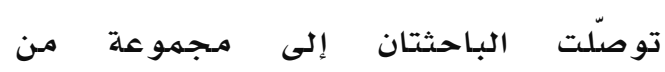

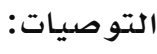

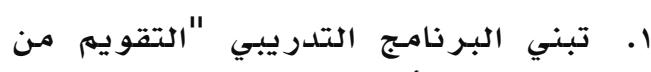

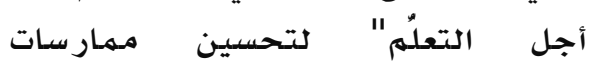

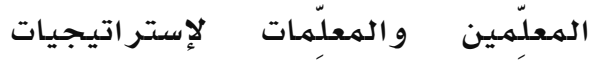
التقويم من أجل التمعلنم.

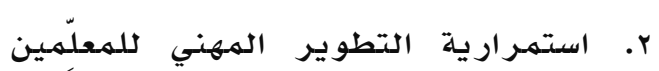

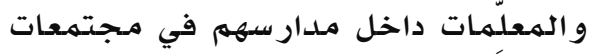

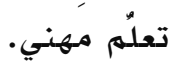

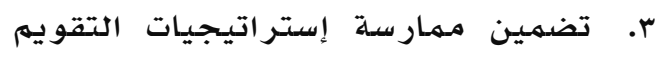

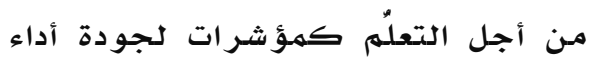

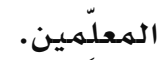

\section{المقترحات}

ا. إجراء دراسات مماثلة للتعرُف على أثر الثرات

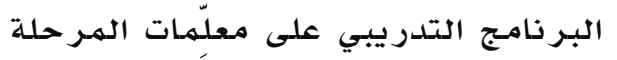
المتو سطة و الثانوية.

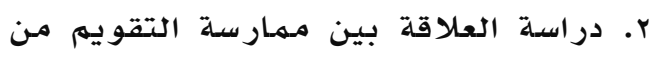

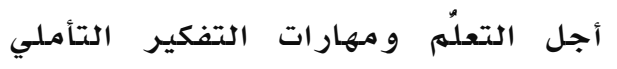

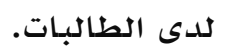

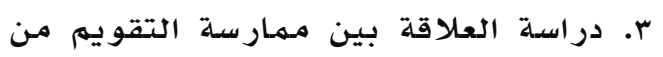

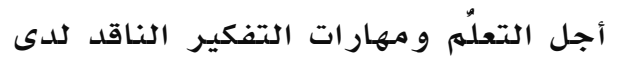

الطالبات.

\section{المراجع}

\section{References}

أبو علام، رجاء. (11) (1). مناهج الدراسة في

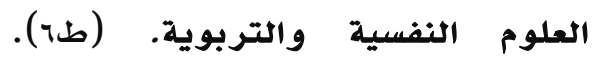
القاهرة: دار الجامعات للنشر.

خليل، محمد. (r..r). أثر استخدام التقويم

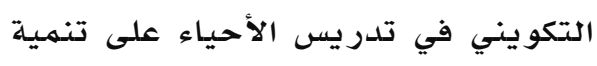

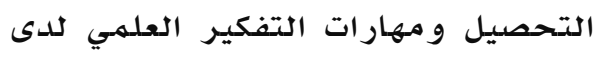

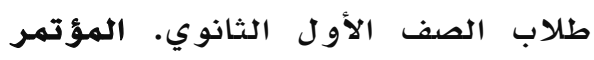
العلمي الخامس عشر (مناهج التعليم الأول الهوتمر

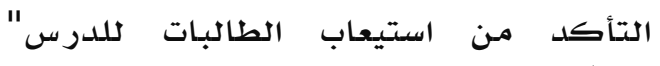

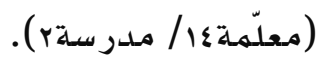

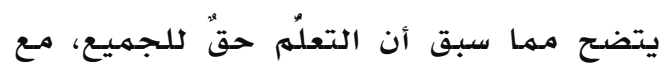

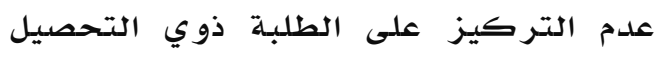

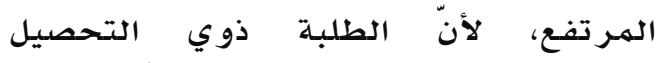

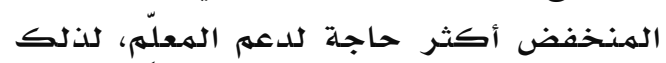

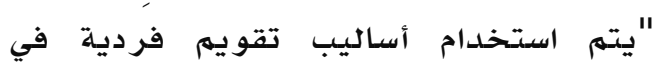
بطاقات يومية للتعرف فلى فلى فهمهن بشكل

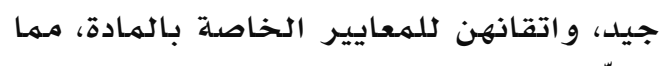

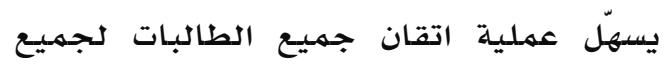

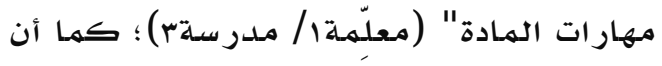

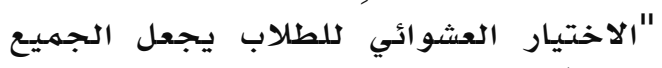

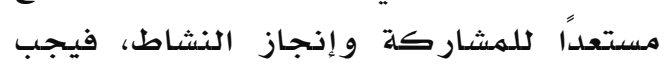

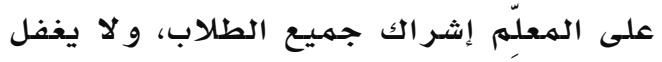

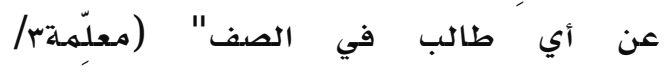
مدرسة) (من). و قد وجدت المعلِّمات أثراً جيدًا على نتائج

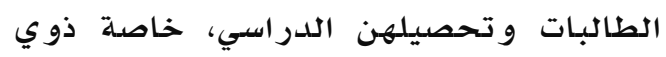

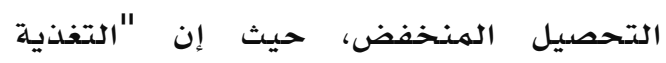
الراجعة لها هدف جميل [على] الطالبة النهفية النهية

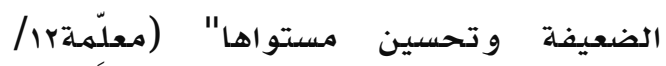

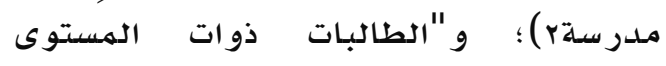

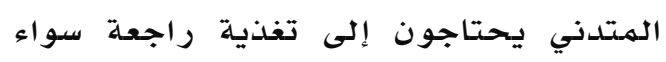

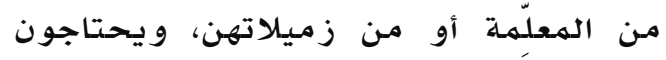

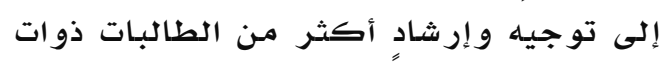

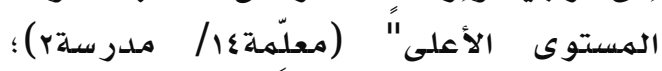

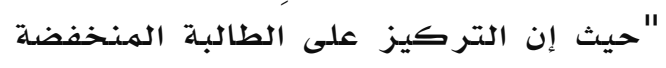

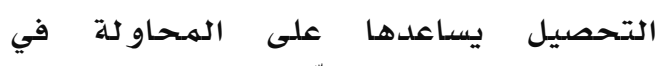

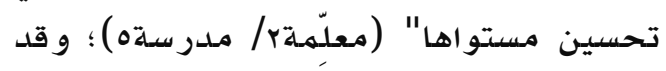

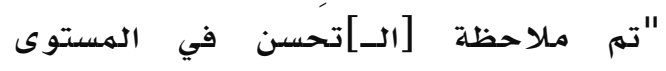

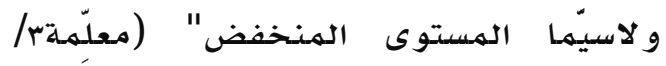
مدر سـة7). و تشير النتائج السابقة إلى فاعلية البرنامج

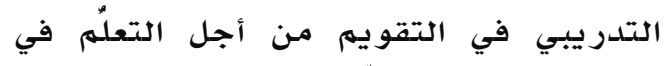

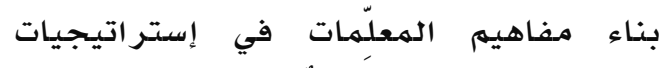

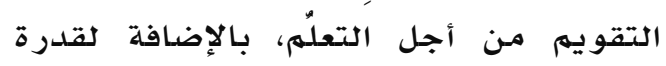

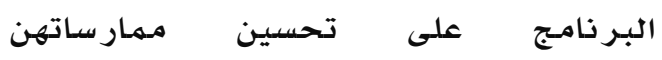
لإستراتيجيات التقويم من أجل التعلُم، الذئي 


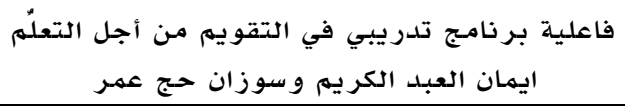

Black, P., \& Wiliam, D. (1998). Assessment and Classroom Learning. Assessment in Education: Principles, Policy \& Practice, 5(1), 7-74.

Black, P. J., \& Wiliam, D. (2009). Developing the theory of formative assessment. Educational Assessment, Evaluation and Accountability, 21(1), 531.

Black, P., \& Wiliam, D. (2010). Inside the Black Box: Raising Standards Through Classroom Assessment. Phi Delta Kappan, 92(1), 81-90.

Chappuis, J., Stiggins, R., Chappuis, S., \& Arter, J. A. (2012). Classroom Assessment for Student Learning (Second Edition). New Jersey: Pearson Education.

Clark, I. (2012). Formative Assessment: Assessment Is for Self-regulated Learning. Educational Psychology Review, 24(2), 205-249.

Clarke, S. (2008). Active Learning through Formative Assessment. London: Hodder Education.

Dweck, C. (2006). Mindset, the New Psychology of Success. New York: Random House.

Fayadh, A. (2017). Effectiveness of the Proposed Training Formative Assessment Programme and its Impact on Teaching Style Improvements of Saudi Science Teachers in Saudi Arabia. Journal of Turkish Science Education (TUSED), 14(1), 35-56.

Gioka, O. (2009). Teacher or Examiner? The Tensions between Formative and Summative Assessment in the Case of Science Coursework. Research in Science Education, 39(4), 411-428.

Harlen, W. (2003). Enhancing Inquiry through Formative Assessment. (J. Brand \& R. Brown, Eds.). San Francisco, Ca.: Exploratorium.

Heritage, M. (2010). Formative Assessment and Next-Generation Assessment Systems: Are We Losing an Opportunity? Council of Chief State School Officers. Retrieved from www.ccsso.org.

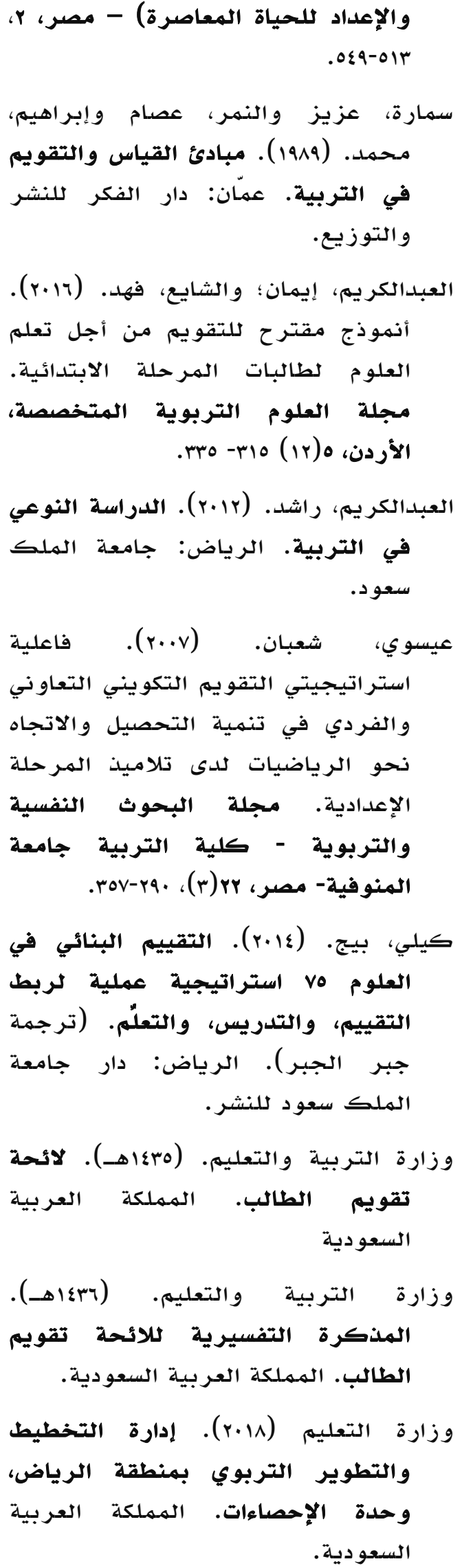


Koh, K., Lim, L., Tan, C., \& Habib, M. (2015). Building Teachers' Capacity in Formative Assessment: the Singapore Example. New Educational Review, 40(2), 211-221.

Piaget, J., \& Inhelder, B. (1969). The Psychology of The Child (2 edition). New York: Basic Books.

Robinson, J., Myran, S., Strauss, R., \& Reed, W. (2014). The impact of an alternative professional development model on teacher practices in formative assessment and student learning. Teacher Development, 18(2), 141-162.

Shepard, L. A. (2000). The Role of Assessment in a Learning Culture. Educational Researcher, 29(7), 4-14.

Wiliam, D. (2011). What is assessment for learning? Studies in Educational Evaluation, 37(1), 3-14.

Wong, M. W. (2007). Assessment for learning and teacher development: the experience of three Hong Kong teachers. Teacher Development, 11(3), 295-312. 